\title{
A Risk Analysis-Best Worst Method Based Model for Selection of the Most Appropriate Contract Strategy for Onshore Drilling Projects in the Iranian Petroleum Industry
}

\author{
Amir Faraji 1,2,*(D), Maria Rashidi ${ }^{3}$, Pegah Khadir ${ }^{4}$ and Srinath Perera ${ }^{2}$ (D) \\ 1 Construction Project Management Department, Faculty of Architecture, Khatam University, Tehran, Iran \\ 2 School of Built Environment, Western Sydney University, Sydney, NSW 2751, Australia; \\ srinath.perera@westernsydney.edu.au \\ 3 Centre for Infrastructure Engineering, Western Sydney University, Sydney, NSW 2751, Australia; \\ m.rashidi@westernsydney.edu.au \\ 4 Construction Project Manager, Iran; pegah_khadir@yahoo.com \\ * Correspondence: a.faraji@khatam.ac.ir or a.faraji@westernsydney.edu.au; Tel.: +98-21-8917-4627
}

\section{check for}

updates

Citation: Faraji, A.; Rashidi, M.; Khadir, P.; Perera, S. A Risk

Analysis-Best Worst Method Based

Model for Selection of the Most

Appropriate Contract Strategy for

Onshore Drilling Projects in the

Iranian Petroleum Industry. Buildings

2021, 11, 97. https://doi.org/

10.3390/buildings11030097

Academic Editors: Agnieszka Leśniak and Krzysztof Zima

Received: 26 January 2021

Accepted: 25 February 2021

Published: 5 March 2021

Publisher's Note: MDPI stays neutral with regard to jurisdictional claims in published maps and institutional affiliations.

Copyright: (c) 2021 by the authors. Licensee MDPI, Basel, Switzerland. This article is an open access article distributed under the terms and conditions of the Creative Commons Attribution (CC BY) license (https:/ / creativecommons.org/licenses/by/ $4.0 /)$.
Abstract: The pre-project planning phase has a significant impact on the achievement of project objectives because during this stage, major decisions including involving contract strategies are made with a high degree of uncertainty. Studies show that the contract type can play a unique role in the achievement of project success. On the other hand, drilling projects can be considered as one of the most critical types of projects in the petroleum industry. In this research, a novel risk based best-worst method (risk-BWM) is proposed for solving the issue of selecting the best contract strategy. A three level methodology was designed; firstly, the risk breakdown structure (RBS) of drilling projects was created in four levels including one heading in level 0, eight main areas of risk in level 1,34 sub-areas of risk in level 2, and finally, 217 risk items in level 3. Secondly and on the basis of BWM, the weights of risk factors were determined as the selection criteria and consequently the best and the worst criteria were specified. Finally, using pair-wise comparisons between six types of drilling prevalent in contracts, the most appropriate contract type was proposed. The contribution of this study is the development of a generic RBS for drilling projects and application of the risk factors for the first time for the selection of contract type using the BWM method, which has the potential of being adapted for other types of underground projects.

Keywords: contract strategy; risk analysis; drilling projects; BWM; RBS

\section{Introduction}

Drilling projects are very expensive efforts which provide high quality data or valuable products for all mineral searching operations [1]. They pinpoint and distinguish economic mineralization in nearly every case, which provides the true challenge for all the theories, concepts, and predictions developed in the previous phases of the searching process for prospect recognition and target generation [2]. Drilling technology is a distinctive field in which nearly all production is carried out underground [3]. One of the key phases of the upstream sector of onshore projects is drilling [4]. The upstream sector encompasses all phases of exploration, which include seismology and associated geological research, together with exploratory and descriptive drilling activities [5]. These types of projects require strategic planning to succeed, because many factors in different levels affect this section of the industry [6]. Therefore, the risk management and administration of uncertainties in these projects, for instance through contractual provisions, become more crucial [7]. The high risk of such activities is among the key elements of upstream onshore operations. However, there are no consistent models that define, classify, and prioritize drilling risks. Even though the risk registry is not accessible for drilling activities, there is a good likelihood that these approaches and databases will be kept by major oil firms as 
technical expertise. It is therefore essential to define and categorize, initially, the challenges underlying this sensitive and significant part of drilling related risk management. It is important to recognize the risks related to the activity in pre-contractual scenarios in which most of the contributing factors have not still been decided. Also, it is highly important to have an appropriate contract for efficient risk management between the contracting parties. Three main conventional drilling contract approaches have been discussed in this study: daily drilling, footage drilling, and turnkey drilling contracts. The most prevalent traditional drilling techniques in upstream oil reserves are these three types of contracts. Considering incentives as a powerful mechanism for achievement of the project objectives increases the potential contractual alternatives from three to six main strategies. However, the lack of investigations on novel contractual solutions, like smart contracts [8], has strongly hindered the whole industry. Getting a good contract becomes much more essential due to the high costs and time invested in onshore and drilling projects. When stakeholders encounter high expenses and multiple risks in these ventures, the value of a strong contract reveals itself, as it adds greatly to the efficiency of the projects, resolves conflicts, and minimizes disagreements. As such, in this analysis, an effective decision method of contract selection as a structured problem $[9,10]$ is offered after considering the risk factors of the oil and gas drilling activity using the multi-criteria decision approach (BWM: best-worst method). The outcomes enable each corporation to obtain, according to its risk acceptance limit, the levels associated with the suggested method and choose the most effective contract structure. By explaining the roles and responsibilities, this approach will greatly reduce the expenses and time needed to finish a project. In the following sections of this paper, the types of drilling contracts and the risks in this industry are introduced and reviewed, the methodology of the study is described, and the proposed RBS, selection criteria weighting method, and contract selection process for an onshore project is illustrated. Finally, the multi-criteria decision making model for selection of the most appropriate drilling contract based on risk analysis is proposed.

\section{Literature Review}

\subsection{Drilling Contracts}

The drilling industry consists of five main markets as illustrated in Figure 1 and the drilling contractor is the central point in this context [6]. The upgrade market is related to maintenance and treatment activities; the secondhand market refers to transactions among contractors to sell and to buy equipment; the scrap market is a section where contractors connect to recycling specialized firms; the newbuilds market refers to the relation between the contractor and other firms willing to buy the contractor company. Although other main decisions including selection of the most qualified sources for the project have a significant impact on project success [11], the contract selection is still considered as the most important stage in the pre-project phase. The types of drilling agreements and the risks in this field are presented and examined below. Also, through considering risk assessments by employing multi-criteria decision-making methods, the most suitable drilling contract is recommended.

Drilling contracts are at the heart of the upstream operational deals. They take different forms and are negotiated to various levels based on the contract value, the level of risk, and the nature of criteria that could be determined by regional forms. The emphasis of this study is on the general conditions of common oil and gas contracts [12]. Three main forms of drilling agreements regulate the drilling of domestic oil and gas wells: footage, day-work, and turnkey. The day-work agreement traditionally is the most frequently used type [6], while in some places or during certain periods, the footage or turnkey based contracts could be utilized [13]. The major alterations between these three primarily relate to whether the risk is estimated and apportioned or not [14]. The incentive mechanisms can be combined to each of the above three contracts and on this basis, the possible forms of agreement increase to six alternatives. However, the incentive contractual mechanisms are described below separately. 


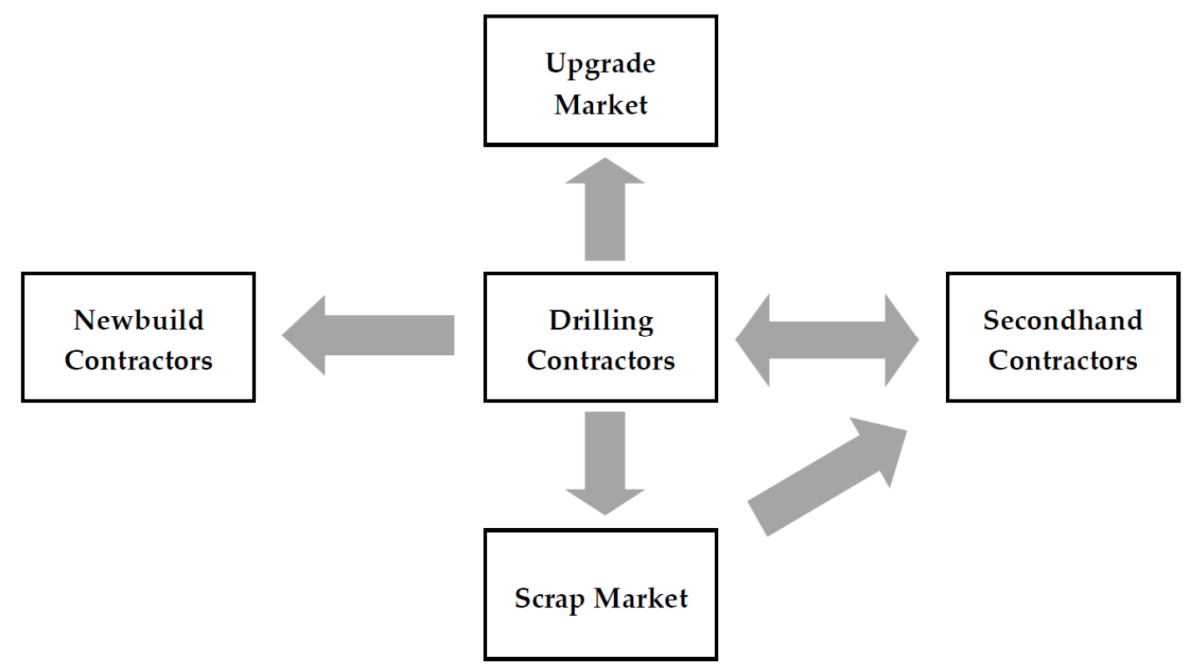

Figure 1. The five main markets of the drilling industry [6].

\subsubsection{Day-Rate Contracts}

Among drilling agreements, one of them is the "day-rate" or "day-work" [15], which is by far the most functional and the most common type of drilling contracts [1]. Here, the contractor shall be charged a set amount (rate) for work produced by the drilling party over a full-day, with the contractor only accepting defined risks and the drilling party having most of the liabilities $[13,16]$. The sum of the specified day-rate depends on a variety of factors, like market conditions, the kind of rig, the number of people in the workforce and the team in charge of furnishing the workforce, the stage of operation, the specialization of the operation, the drill pipe, other machinery, and special services. The day-rate can vary at different points of project execution. Moreover, a day-rate contract can allow for lump-sum payments for specialized tasks, including deployment and layoffs $[13,14]$. Day-work contracts that are commonly used for drilling wells do not create a possibility for the contractor to make profits that could lead to a rise in efficiency or a reduction in well expenses [17]. Day charges operate on demand and supply dynamics in a way that, when demand for a rig goes beyond supply, day rates increase $[11,18]$. When demand for rigs, particularly those built for a specific purpose, like drilling of a deeper well is at its peak, the drilling operator might ask for a "term day-work" agreement. Within this form of contract, the provider is allowed to expect, for the duration of the contract, a certain day-rate, whether or not the rig is working, standing, or rigged and inactive [13]. A detailed drilling service is provided by the well operator to guide the contractor on how to move ahead with the well, including all the well supplies and any service needed for the well. To mine the well, the drilling contractor supplies drilling tools and staff [19]. Providers have a delegate at the project location. Like management at the rig, the payment system is basically a provider process [16]. Day-work contracts offer a degree of leeway for the provider to modify the work order. At the same time, the contractor would not be given a motivation plan to finish the job more efficiently and at a low cost. Thus, opposed to the primary estimate, there seems to be an inclination to raise costs and time [20]. The drilling party is accountable for the defined risks under the day-rate contract, whereas the provider is accountable for the overall risk of delay or even for the risk of liability not borne by the contractor [13]. In such a deal, the contractor is just responsible for the risks of the machinery, services offered, and the supply of the workforce. All the remaining risks rest on the operator [3].

\subsubsection{Footage Contracts}

The footage drilling agreement is used in places where drilling expenses can be efficiently anticipated in onshore regions where multiple wells are drilled [21]. A footage contract offers the fixed price per foot for the hole drilled from the ground to the maximum 
depth or for any other task required to be paid to the drilling contractor [13]. Essentially, a "footage" contract stipulates that the drilling service provider supplies the drilling staff, the equipment, and certain defined services as well. In a footage contract, the provider undertakes more well-related risk compared to a day-rate contract that is adjusted by a slightly higher price to the operator. The value of such a deal increases if the contractor can drill more effectively than expected. However, if the well faces problems and requires more for each well drilled per foot, then the drilling party pays the extra cost and can lose money [14]. Since the drilling party is compensated just for footage drilled and the specified day-rate, and since it takes on more risk, a footage agreement is considered to be more beneficial to the operator compared to a day-work agreement [13]. Footage deals are mostly considered for the area above the potential reservoir where, from an assessment or processing perspective, hole factors are less important [4].

\subsubsection{Turnkey Contracts}

A "turnkey" agreement allows for a fixed price to be given to the drilling party to drill a well to a required depth or identified formation [13]. This price concerns the supply by the drilling party of all services, such as the workforce, drilling rigs, machinery, equipment, and particular services. Once the operation is completed, the negotiated amount can be reimbursed and the well is dug to a specific depth (Contract Depth) [22]. The complication with this plan is making sure that the company is provided with a "quality well" because the drilling party wants to dig as quickly and frugally as possible. Thus, for each well, the drilling party should ensure there is an agreed objective quality level. The assurance must determine remedial steps to be carried out if a substandard well is delivered [4]. For the drilling party, a pure turnkey agreement offers the highest risk as well as the highest reward. With this type of agreement, for a lumpsum, set price, a drilling contractor is obliged to drill the well completely. The drilling contractor covers all the expenses and risks of the work and makes contracts for machinery and services with third parties. Therefore, to minimize the risk ingrained in drilling wells, operators choose turnkey contracts [14]. Since the drilling party assumes all risks, the actual anticipation of the "cost" of the well must be increased to reduce such risks. The potential cost of these risks is applied to the projected real cost, and the profit margin, to achieve a turnkey bid price [21].

\subsubsection{Incentive Contracts}

Conventionally, incentive agreements (sometimes referred to as "risk contracts") are based on footage or turnkey ideas in the drilling sector [23]. Today, however, despite the form of agreement used, steps have been taken to guarantee that the arrangement between the parties provides motivations in line with the conditions of each contract. Incentive agreements are a way of forming a connection between the sums charged and the efficacy of the services provided by the operator. In this type of contracts, objectives are established based on capability standards. The costs of services are then changed based on the achievement of the intended targets. The productivity-based price change is an efficient way to attract contractors. Therefore, accomplishing the drilling objectives results in rewarding the contractor, and failure to deliver them will lead to a fine [24]. Recently, this approach of engaging in drilling activities has been implemented very efficiently and has led to a considerable reduction in expenses. Different systems are in deployment, generally offering a bonus for greater productivity than average. The contractor is in accord with the company on the requirements for the well. Thus, the 'historic' cost is delineated for similar wells that have been drilled already. This enables the projected cost of the new well to be calculated. The drilling party will be solely responsible for digging the well, and the company and the contractor will divide the cost savings obtained.

\subsection{Risk Analysis of Drilling Projects}

Risk can be defined in various ways. The established outlooks and meanings of risk are centered on probabilities [25]. PMBOK (2018) describes risk as any "uncertain 
event or condition that, if it occurs, has a positive or negative effect, such as time, cost, scope or quality, on at least one project objective." Wideman (1992) describes project risk as "the cumulative effect of the chances of uncertainty occurrences adversely affecting project objectives" [26]. Some more risk definitions are as follows: Risk is a way of measuring the possibility and severity of undesirable reactions [27]; Risk is a combination of the possibility of a situation and its repercussions [28]. As long as they are in step with the benefits, certain risks should be considered. Risks pose threats to the progress of ventures. It has been shown that failure to properly manage risks causes time and cost overruns in activities [29]. For all these concepts, what is similar is that events (initiating incidents, scenarios), consequences (results), and probabilities are included in the definition of risk. Uncertainties are stated through probabilities [25]. It is worth mentioning that there are theoretical differences between application of the risk and the uncertainty concepts; whereas risk refers to circumstances where the possible consequences and their probabilities are determinable for the decision-maker, uncertainty is used for situations that the probability and impact of occurrences are completely unknown [30,31].

\subsubsection{Risks of Contract}

The term 'risk allocation' is widely used to define responsibilities. The distribution of responsibilities among each of the parties to the contract is a basic component of contract terms. There is a hypothesis that responsibilities should be assigned based on who is in the right position to manage risks or for whom those risks are economically feasible. It may be argued that the exercise of obligation distribution should be done in the most balanced way. It seems that the client should assume those liabilities and risks, which really are under the command of the client and the contractor should assume the liabilities and risks that are under the command of the contractor.

\subsubsection{Risk Management in Drilling Process}

Drilling is a strategic and vital activity, featuring practices that are dynamic and dangerous in resource exploration [32]. A danger is any unscheduled event (risk) or incident likely to cause a drilling process to diverge from its predefined strategy or critical path [33]. These unplanned incidents give rise to events ranging from unproductive drilling time or marginal impacts on the drilling (small amounts of fluid wasted) to serious wellbore malfunctions and a lack of command in the drilling process. It is also described as "trouble." Not only geological uncertainty, but also mechanical issues or human errors are the results of these incidents. Finally, the drilling schedule, budget, project completion, and credibility of the companies concerned will be impacted by these disruptions [34]. More updated information surfaces when the drilling starts and some expected hazards may still cause harm, whereas others may not. It is possible to discover and identify new hazardous situations, and the nature of those that are already known may change. Risk management should also be planned out at all levels of the project regularly, that is before, during, or after drilling [35]. Of the most significant elements of setting up subsurface geology in engineering projects is the management of drilling hazards. Drilling risks resulting from geological uncertainties, technical problems, environmental extremes [36,37], or human error have been reported at coastal and terrestrial sites [33]. A Risk management process includes the procedures for the preparation, assessment, review, response planning, implementation of responses, and control of the risk of the work [38]. The primary goal is to define and monitor the most relevant risks [39]. The most critical hazards in the drilling sector must therefore be identified [29]. Either internal or external risks threaten drilling programs. All the risks could hurt the project's budget, schedule, or efficiency. Risk management should therefore be well understood and managed as an interconnected project management feature [40]. 


\section{Research Methodology}

To achieve the research's objectives including: 1 . Recognition of the main risks of drilling projects in Iranian onshore oil fields, 2. Ranking identified risks, and 3. Selection of the most appropriate drilling contract based on risk analysis, a three levels methodology was created. In the first step, to recognize the uncertainties and challenges of drilling projects in a hierarchical manner, a questionnaire was designed in a closed format. In this questionnaire, data relating to risks in drilling projects were gathered and subsequently organized into a proposed structure. The experts were asked to add, amend, or delete items as required, reaching consensus among experts towards the end of the process. The input of the first stage was a basic structured data of disputes extracted from the literature review and the output was the risk breakdown structure (RBS) of drilling projects. We explained that in reviewing the available resources, the researchers were looking for items that have been introduced in previous references as possible and probable risk parameters affecting drilling projects that, if they occur, affect one of the predetermined objectives. These sources are listed in the presented table in the Appendix A. The second questionnaire was designed to obtain the experts' judgments about the risks occurrence probability and their prospective impact on the project objectives. The key project objectives including cost, time, quality, environment, and safety were adopted in this regard. The input of this stage was the RBS and the output was the estimation of probability and impact assessment of the recognized risks. On the basis of the above quantitative analysis using the opinion of the experts, 35 of the most effective risks were selected for applying in a project contract strategy selection model. Finally, the experts were asked to assess the appropriateness of contract alternatives against the selected risks, and then the most appropriate contract strategy was proposed based on the BWM method. Since there is no reliable database which has organized and has assessed the risks of drilling projects, acquiring the experts' opinions was considered as the most reliable method and therefore all above data gathering procedures were programmed in a Delphi process. In this regard, a two round Delphi technique (for each stage) with a panel including eight experts who had one of the following three characteristics were considered:

- At least eight years' experience in management of drilling contracts; or

- At least 10 years' experience in academic research on drilling contracts; or

- At least having a master's degree in petroleum project management.

- The research methodology and its elements are shown in Figure 2.

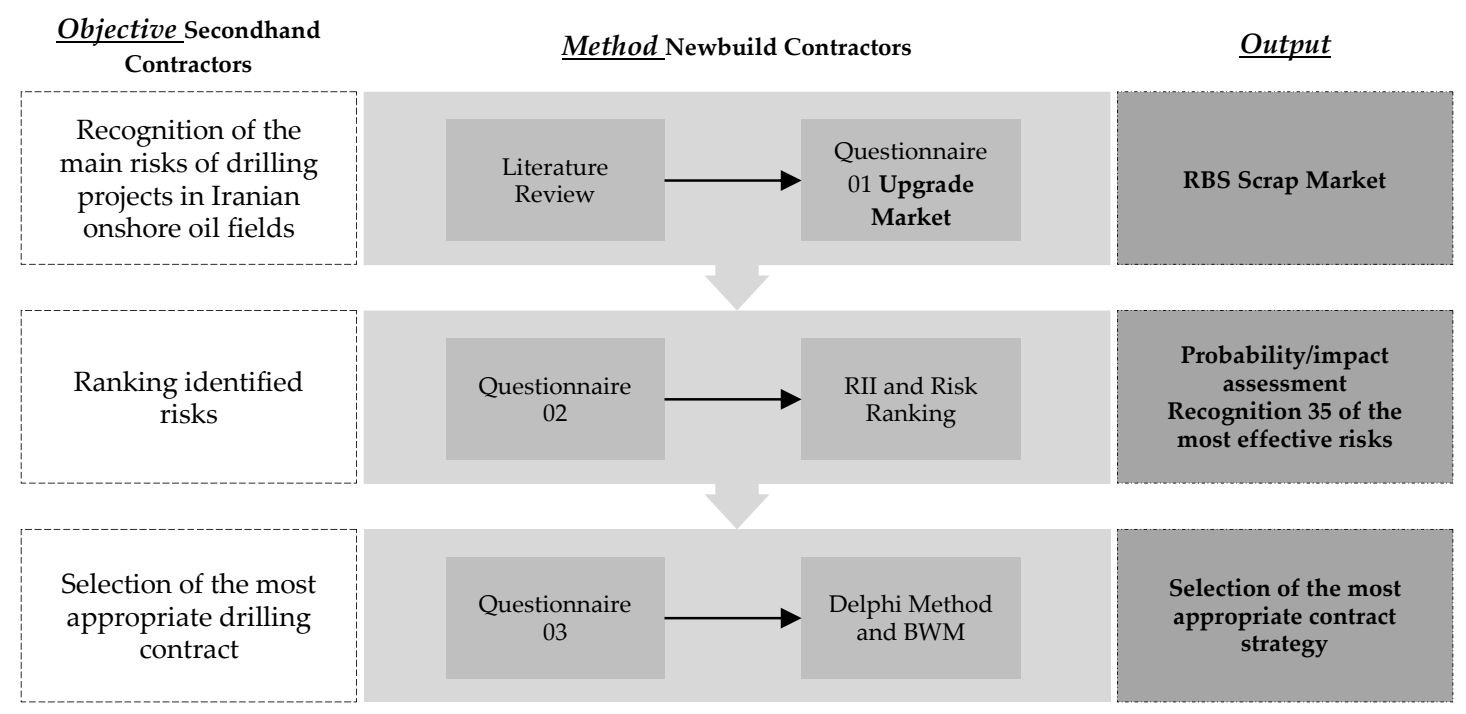

Figure 2. Objectives, methods, and outputs in each stage of the research methodology. 
The Best Worst Method (BWM) is a multi-criteria decision-making method developed by Jafar Rezaei [41]. In order to identify the weights of parameters, BWM utilizes two sets of pairwise comparisons. It contrasts the best parameter with the other parameters and the worst parameter with all the other parameters. The objective was to find the optimum proportion of weights and consistency by means of a standard linear optimization model developed by a comparative system [42]. The BWM previously has been applied in a vast spectrum of research in the construction area such as the supplier selection [43-45], the contractor selection [46,47], site selection [48,49], and risk assessment [50,51]. Previous investigations demonstrate that the BWM method can lead to more consistent pair-wise comparisons and outcomes with higher reliability than conventional approaches. The Analytical Hierarchy Process (AHP) could be known as a multi decision-making strategy that can incorporate qualitative and quantitative variables in the overall assessment of alternatives $[52,53]$. It comprises three sections: the hierarchical structure, the pairwise comparative matrix, and the priority calculation method. The AHP evaluates the priority of any alternative to the overall objective of the issue of concern. At the peak of the hierarchy lies the ultimate target or the main objective. Subsequent lower levels then reflect a progressive dissolution of the alternatives to the problem. A decision-maker or a qualified party will perform a pairwise analysis of all the items at each point related to each of the project items at the higher step of the hierarchy. The pairwise analysis is founded on a range of 1-9, as described in Table 1 [54]. The formation of these decisions sets the criticality of the items at the lowest point (generally solution alternates) related to the achievement of the highest objective [53].

Table 1. The comparison scale of the Analytical Hierarchy Process (AHP) method.

\begin{tabular}{cc}
\hline Weight & Definition \\
\hline 1 & Equal importance \\
5 & Weak importance of one over another \\
7 & Essential or strong importance \\
9 & Very strong importance \\
$2,4,6,8$ & Absolute importance \\
Reciprocals of previous values & If factor " $i$ " has one of the previously mentioned numbers assigned to it when compared to \\
factor " $j$, , then $j$ has the reciprocal value when compared with $i$
\end{tabular}

\section{Data Analysis and Results}

\subsection{Risk Analysis to Develop the Selection Criteria}

As discussed earlier, due to the lack of a coherent database of risks of drilling projects, despite the experience of hundreds of drilling projects in Iran and even a lack of access to such a bank internationally, the risks were first identified using the study of previous research and available technical documents. However, overall 217 risks were recognized: 122 items from the literature review and 95 items from the first stage of the methodology, including two rounds of the Delphi method. Therefore, in this process, a comprehensive list of potential risks of drilling contracts was formed and at the same time a categorizing procedure for rolling up the risks in a class was done. Thus, the output of this stage was the risk breakdown structure (RBS) of drilling projects of the petroleum industry as a generic list of potential uncertainties. The proposed RBS consists of one heading in level 0, eight main areas of risk in level 1, 34 sub-areas of risk in level 2, and finally 217 risk items in level 3. The comprehensive list of recognized risks in the form of RBS of drilling projects is shown in Appendix A. Figure 3 illustrates the four levels of the risk structure for organizational risks and organization related items. 


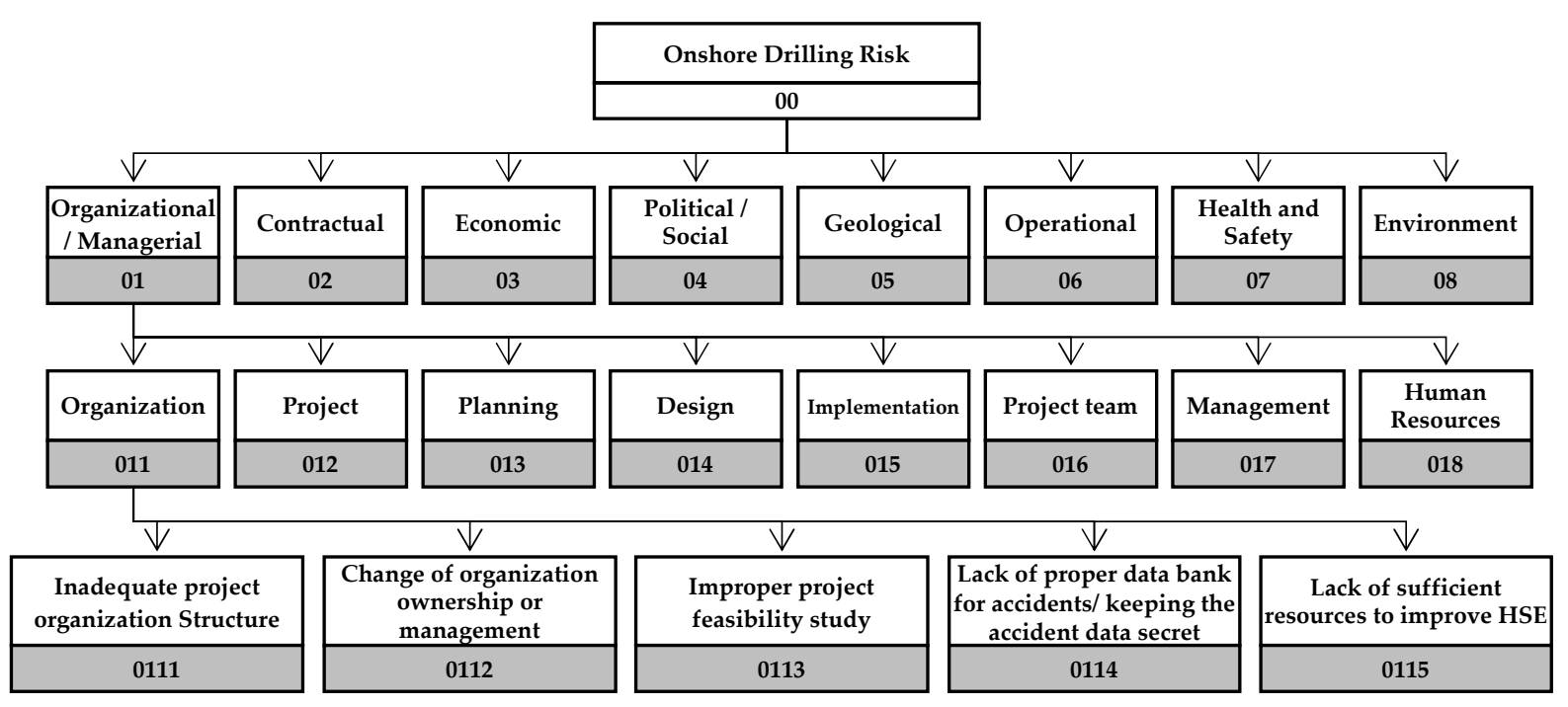

Figure 3. Hierarchical view of the proposed risk breakdown structure (RBS) for drilling projects (level 0, 1, 2, and 3 of branch 01).

Obviously, the importance of the recognized risks is not equal for all drilling projects and therefore, it was essential to rank them and to focus on the most effective items. In order to examine the prioritizing procedure of the potential risks, a real drilling project with the following eight features was selected:

1. Onshore project

2. Oil field with about 10 years production (brown field)

3. Sandstone formation with low porosity

4. Homogeneous formation without fracture

5. Drilling depth up to $100 \mathrm{~m}$

6. Vertical drilling method

7. Available data of previous well drillings

8. Conventional access to the well drilling location.

Based on the experts' opinions, the probability of risk occurrence and also their impacts on objectives of the defined project have been judged. Using the average of gathered data, the risk importance index (RII) was calculated based on the Equation (1):

$$
R I I_{R i}=\frac{1}{5} \sum_{j=1}^{5} P_{i} I_{k j}
$$

where $R I I_{R i}$ indicates the risk importance index of risk $R i$ on project objective $k$, $k \in$ \{cost,time,quality,environment,safety\}, $P_{i}$ is the probability of occurrence of $R i$ and $I_{k j}$ is the impact of risk $R i$ on the project objective $k$. The higher value of RII presents an overall risk significance in the project parameters. Table 2 represents the top ranked risk importance index of drilling projects' ${ }^{\prime}$ risks and impact of them on the five main project objectives including the cost, time, quality, safety, and environment. The cutting line for top risks was determined to be the minimum overall impact of 0.4 on project objectives based on the 35 high risks that have been identified. It should be mentioned that the cutting point have been applied on each of eight main areas, in order to build a more balanced list of high risks. Also, Table 3 summarizes the top 10 ranked risks which have the most impact on a specified project objective. Figure 4a shows the overall top ten most effective risks and Figures $4 \mathrm{~b}, 5$ and 6 demonstrate this index per each project objective. 
Table 2. The list of risks with the highest RII.

\begin{tabular}{|c|c|c|c|c|c|c|c|c|c|}
\hline \multirow{2}{*}{ Risk Code } & \multirow{2}{*}{ Description of Risk } & \multirow{2}{*}{ RBS Code } & \multirow{2}{*}{ Probability } & \multicolumn{5}{|c|}{ Impacts on Project Objectives } & \multirow{2}{*}{ RII } \\
\hline & & & & Cost & Time & Quality & Environment & Safety & \\
\hline R1 & $\begin{array}{l}\text { Blow out of project } \\
\text { contingency }\end{array}$ & 6601 & 0.55 & 5.206 & 4.250 & 4.327 & 3.331 & 4.082 & 4.239 \\
\hline R2 & $\begin{array}{l}\text { Tight hole of the well and } \\
\text { casing run problems }\end{array}$ & 6109 & 0.42 & 3.198 & 2.753 & 2.808 & 2.474 & 2.939 & 2.834 \\
\hline R3 & Pipe failure & 6201 & 0.45 & 3.805 & 4.418 & 3.156 & 0.953 & 1.702 & 2.807 \\
\hline $\mathrm{R} 4$ & $\begin{array}{l}\text { Changes in the size of the } \\
\text { inner diameter of the } \\
\text { casing in some parts due } \\
\text { to impact }\end{array}$ & 6106 & 0.42 & 3.736 & 3.877 & 2.700 & 1.907 & 1.421 & 2.728 \\
\hline R5 & $\begin{array}{l}\text { Lack of well rehabilitation } \\
\text { before casing running } \\
\text { operations and the } \\
\text { resulting problems }\end{array}$ & 6101 & 0.45 & 3.988 & 3.602 & 3.233 & 1.349 & 1.400 & 2.714 \\
\hline R6 & $\begin{array}{l}\text { Collapsing formation and } \\
\text { wellbore instability }\end{array}$ & 6701 & 0.45 & 3.640 & 3.961 & 3.444 & 0.362 & 0.971 & 2.476 \\
\hline R7 & $\begin{array}{l}\text { Poor design and late } \\
\text { changes to well design } \\
\text { and procedures }\end{array}$ & 1403 & 0.46 & 4.108 & 4.875 & 2.830 & 0.124 & 0.241 & 2.436 \\
\hline R8 & Loss of circulation & 6401 & 0.42 & 3.678 & 3.033 & 3.055 & 0.069 & 0.940 & 2.155 \\
\hline R9 & $\begin{array}{l}\text { Sanctions and } \\
\text { special bans }\end{array}$ & 4205 & 0.35 & 2.235 & 2.547 & 1.660 & 0.852 & 2.782 & 2.015 \\
\hline R10 & $\begin{array}{l}\text { Incompetence of } \\
\text { project team }\end{array}$ & 1601 & 0.35 & 3.598 & 2.806 & 3.104 & 0.133 & 0.111 & 1.951 \\
\hline R11 & Equipment failure & 6809 & 0.35 & 2.262 & 2.764 & 2.681 & 0.707 & 1.337 & 1.950 \\
\hline R12 & $\begin{array}{l}\text { Blocking of the drilling } \\
\text { pipe or product pipe } \\
\text { installation due to the } \\
\text { swelling of clay and silt }\end{array}$ & 6208 & 0.39 & 3.663 & 3.274 & 2.344 & 0.237 & 0.173 & 1.938 \\
\hline R13 & Exchange rate changes & 3104 & 0.35 & 2.495 & 2.997 & 2.038 & 0.733 & 1.154 & 1.883 \\
\hline R14 & $\begin{array}{l}\text { Weakness in planning } \\
\text { and scheduling and initial } \\
\text { project resources }\end{array}$ & 1301 & 0.31 & 2.095 & 1.998 & 2.215 & 1.480 & 1.525 & 1.863 \\
\hline R15 & $\begin{array}{l}\text { Infiltration of drilling } \\
\text { mud into wells }\end{array}$ & 6501 & 0.32 & 2.498 & 2.607 & 1.575 & 0.800 & 0.467 & 1.589 \\
\hline R16 & $\begin{array}{l}\text { Excessive delays due to } \\
\text { late decisions making by } \\
\text { project participants }\end{array}$ & 1606 & 0.31 & 2.413 & 2.704 & 1.071 & 0.481 & 0.781 & 1.490 \\
\hline R17 & $\begin{array}{l}\text { Problems in casing } \\
\text { cementing and Staying } \\
\text { cement in casing }\end{array}$ & 6303 & 0.25 & 1.653 & 1.675 & 1.325 & 0.825 & 0.691 & 1.234 \\
\hline R18 & $\begin{array}{l}\text { Ambiguous conditions } \\
\text { of contract }\end{array}$ & 2102 & 0.25 & 1.520 & 1.878 & 1.183 & 0.612 & 0.693 & 1.177 \\
\hline R19 & $\begin{array}{l}\text { Inappropriate choice } \\
\text { of project } \\
\text { implementation method }\end{array}$ & 1501 & 0.21 & 1.129 & 1.409 & 1.383 & 0.306 & 1.152 & 1.076 \\
\hline R20 & $\begin{array}{l}\text { Corrosion or wear of } \\
\text { mechanical parts }\end{array}$ & 6801 & 0.25 & 1.953 & 1.447 & 0.981 & 0.157 & 0.472 & 1.002 \\
\hline $\mathrm{R} 21$ & $\begin{array}{l}\text { Error in measuring the } \\
\text { correct weight of cement }\end{array}$ & 6308 & 0.23 & 1.445 & 1.323 & 1.269 & 0.625 & 0.290 & 0.990 \\
\hline R22 & $\begin{array}{l}\text { Lack of skills of drilling } \\
\text { staff (inadequate practice } \\
\text { of skills) }\end{array}$ & 1801 & 0.23 & 1.426 & 1.199 & 1.196 & 0.515 & 0.567 & 0.981 \\
\hline
\end{tabular}


Table 2. Cont.

\begin{tabular}{|c|c|c|c|c|c|c|c|c|c|}
\hline \multirow{2}{*}{ Risk Code } & \multirow{2}{*}{ Description of Risk } & \multirow{2}{*}{ RBS Code } & \multirow{2}{*}{ Probability } & \multicolumn{5}{|c|}{ Impacts on Project Objectives } & \multirow{2}{*}{ RII } \\
\hline & & & & Cost & Time & Quality & Environment & Safety & \\
\hline $\mathrm{R} 23$ & $\begin{array}{c}\text { Work conditions } \\
\text { deferring from contract }\end{array}$ & 2104 & 0.16 & 1.127 & 1.294 & 0.851 & 0.443 & 0.753 & 0.894 \\
\hline R24 & $\begin{array}{l}\text { Change in rules } \\
\text { and regulations }\end{array}$ & 4107 & 0.22 & 1.486 & 1.538 & 0.759 & 0.270 & 0.115 & 0.834 \\
\hline R25 & $\begin{array}{l}\text { Improper cost } \\
\text { calculations for } \\
\text { the investment }\end{array}$ & 3203 & 0.15 & 0.818 & 0.707 & 0.715 & 1.052 & 0.834 & 0.825 \\
\hline R26 & $\begin{array}{l}\text { Inadequate project } \\
\text { organization structure }\end{array}$ & 1101 & 0.21 & 1.590 & 1.059 & 0.652 & 0.089 & 0.545 & 0.787 \\
\hline $\mathrm{R} 27$ & $\begin{array}{l}\text { Unclear and imprecise } \\
\text { delegation of } \\
\text { responsibilities and roles } \\
\text { and project charter }\end{array}$ & 1203 & 0.16 & 1.001 & 0.891 & 0.612 & 0.615 & 0.792 & 0.782 \\
\hline R28 & $\begin{array}{c}\text { Change of organization } \\
\text { ownership } \\
\text { or management }\end{array}$ & 1102 & 0.22 & 1.105 & 1.163 & 0.847 & 0.036 & 0.547 & 0.739 \\
\hline $\mathrm{R} 29$ & $\begin{array}{l}\text { Acidizing which causes } \\
\text { cracking of lines and } \\
\text { hitting people, acid } \\
\text { spraying and severe } \\
\text { acid burns }\end{array}$ & 7104 & 0.18 & 1.083 & 1.050 & 0.947 & 0.056 & 0.460 & 0.719 \\
\hline R30 & $\begin{array}{c}\text { New and complex } \\
\text { technology (e.g., packers } \\
\text { and liner hangers) }\end{array}$ & 6901 & 0.16 & 0.992 & 1.104 & 0.650 & 0.105 & 0.627 & 0.696 \\
\hline R31 & $\begin{array}{l}\text { Geological structure and } \\
\text { complexity of the region }\end{array}$ & 5101 & 0.15 & 1.011 & 0.811 & 1.035 & 0.118 & 0.107 & 0.616 \\
\hline R32 & $\begin{array}{l}\text { Oil and gas leaks, toxic } \\
\text { gas leaks, waste, or other } \\
\text { environmental pollutants }\end{array}$ & 8501 & 0.14 & 1.026 & 0.929 & 0.383 & 0.281 & 0.460 & 0.616 \\
\hline R33 & $\begin{array}{l}\text { Disposal and discharge of } \\
\text { wastewater and } \\
\text { drilling fluid }\end{array}$ & 8301 & 0.15 & 0.730 & 0.144 & 0.057 & 1.213 & 0.037 & 0.436 \\
\hline R34 & $\begin{array}{l}\text { Lack of sufficient } \\
\text { knowledge and } \\
\text { information of field and } \\
\text { reservoir structures }\end{array}$ & 5202 & 0.15 & 0.766 & 0.067 & 0.010 & 1.230 & 0.072 & 0.429 \\
\hline R35 & $\begin{array}{l}\text { Changing social } \\
\text { responsibility rules } \\
\text { and regulations }\end{array}$ & 4303 & 0.14 & 0.440 & 0.653 & 0.485 & 0.115 & 0.336 & 0.406 \\
\hline
\end{tabular}

Table 3. The top risks versus each objective of the drilling project.

\begin{tabular}{ccll}
\hline Project Objective & Risk Code & \multicolumn{1}{c}{ Description of the Risk } & RII \\
\hline R1 & Blow out of project contingency & 5.206 \\
R7 & Poor design and late changes to well design & 4.108 \\
R5 & and procedures & Pipe failure & 3.988 \\
R3 & Tight hole of the well and casing run problems & 3.805 \\
R4 & Loss of circulation & 3.736 \\
R8 & R12 & Lack of well rehabilitation before casing running & 3.678 \\
& R6 & Sanctions and special bans problems & 3.663 \\
R10 & Changes in the size of the inner diameter of the casing in & 3.640 \\
R2 & some parts due to impact & Exchange rate changes & 3.598 \\
\end{tabular}


Table 3. Cont.

\begin{tabular}{|c|c|c|c|}
\hline Project Objective & Risk Code & Description of the Risk & RII \\
\hline \multirow{10}{*}{ Time } & R7 & $\begin{array}{l}\text { Poor design and late changes to well design } \\
\text { and procedures }\end{array}$ & 4.875 \\
\hline & $\mathrm{R} 3$ & Tight hole of the well and casing run problems & 4.418 \\
\hline & $\mathrm{R} 1$ & Blow out of project contingency & 4.250 \\
\hline & R6 & $\begin{array}{l}\text { Changes in the size of the inner diameter of the casing in } \\
\text { some parts due to impact }\end{array}$ & 3.961 \\
\hline & $\mathrm{R} 4$ & Loss of circulation & 3.877 \\
\hline & $\mathrm{R} 5$ & Pipe failure & 3.602 \\
\hline & $\mathrm{R} 12$ & Sanctions and special bans & 3.274 \\
\hline & R8 & $\begin{array}{l}\text { Lack of well rehabilitation before casing running } \\
\text { operations and the resulting problems }\end{array}$ & 3.033 \\
\hline & R13 & $\begin{array}{l}\text { Blocking of the drilling pipe or product pipe installation } \\
\text { due to the swelling of clay and silt }\end{array}$ & 2.997 \\
\hline & R10 & Exchange rate changes & 2.806 \\
\hline \multirow{10}{*}{ Quality } & $\mathrm{R} 1$ & Blow out contingency & 4.327 \\
\hline & R6 & $\begin{array}{l}\text { Changes in the size of the inner diameter of the casing in } \\
\text { some parts due to impact }\end{array}$ & 3.444 \\
\hline & R5 & Pipe failure & 3.233 \\
\hline & R3 & Tight hole of the well and casing run problems & 3.156 \\
\hline & $\mathrm{R} 10$ & Exchange rate changes & 3.104 \\
\hline & $\mathrm{R} 8$ & $\begin{array}{l}\text { Lack of well rehabilitation before casing running } \\
\text { operations and the resulting problems }\end{array}$ & 3.055 \\
\hline & R7 & $\begin{array}{l}\text { Poor design and late changes to well design } \\
\text { and procedures }\end{array}$ & 2.830 \\
\hline & $\mathrm{R} 2$ & Collapsing formation and wellbore instability & 2.808 \\
\hline & $\mathrm{R} 4$ & Loss of circulation & 2.700 \\
\hline & R11 & Incompetence of project team & 2.681 \\
\hline \multirow{10}{*}{ Environment } & $\mathrm{R} 1$ & Blow out contingency & 3.331 \\
\hline & $\mathrm{R} 2$ & Collapsing formation and wellbore instability & 2.474 \\
\hline & $\mathrm{R} 4$ & Loss of circulation & 1.907 \\
\hline & $\mathrm{R} 14$ & Infiltration of drilling mud into wells & 1.480 \\
\hline & R5 & Pipe failure & 1.349 \\
\hline & R34 & Disposal and discharge of wastewater and drilling fluid & 1.230 \\
\hline & R33 & $\begin{array}{l}\text { Oil and gas leaks, toxic gas leaks, waste, or other } \\
\text { environmental pollutants }\end{array}$ & 1.213 \\
\hline & $\mathrm{R} 25$ & $\begin{array}{l}\text { Acidizing which causes cracking of lines and hitting } \\
\text { people, acid spraying, and severe acid burns }\end{array}$ & 1.052 \\
\hline & $\mathrm{R} 3$ & Tight hole of the well and casing run problems & 0.953 \\
\hline & R9 & Equipment Failure & 0.852 \\
\hline \multirow{10}{*}{ Safety } & R1 & Blow out contingency & 4.082 \\
\hline & $\mathrm{R} 2$ & Collapsing formation and wellbore instability & 2.939 \\
\hline & $\mathrm{R} 9$ & Equipment Failure & 2.782 \\
\hline & $\mathrm{R} 3$ & Tight hole of the well and casing run problems & 1.702 \\
\hline & $\mathrm{R} 14$ & Infiltration of drilling mud into wells & 1.525 \\
\hline & $\mathrm{R} 4$ & Loss of circulation & 1.421 \\
\hline & $\mathrm{R} 5$ & Pipe failure & 1.400 \\
\hline & R11 & Incompetence of project team & 1.337 \\
\hline & $\mathrm{R} 13$ & $\begin{array}{l}\text { Blocking of the drilling pipe or product pipe installation } \\
\text { due to the swelling of clay and silt }\end{array}$ & 1.154 \\
\hline & R19 & $\begin{array}{l}\text { Lack of skills of drilling staff (inadequate practice } \\
\text { of skills) }\end{array}$ & 1.152 \\
\hline
\end{tabular}




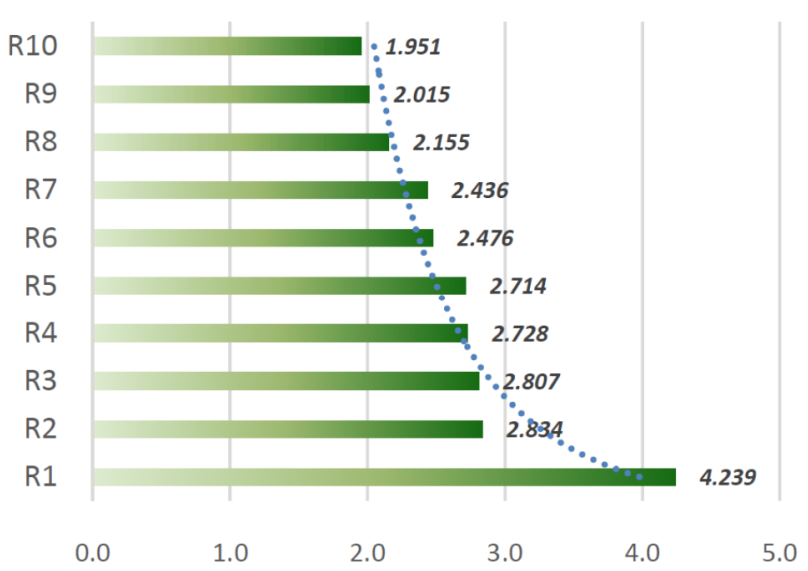

(a)

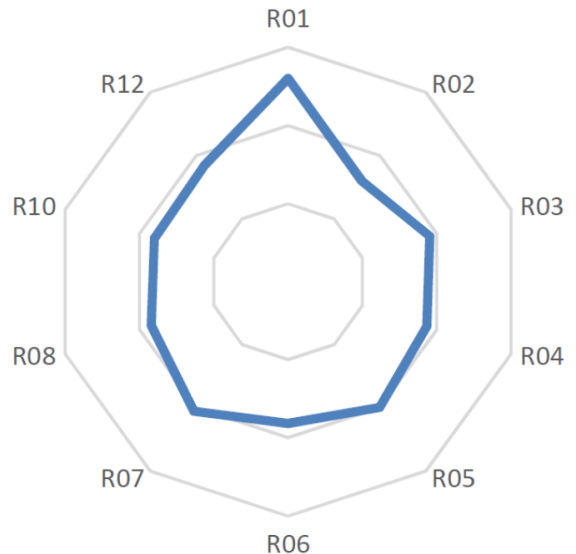

(b)

Figure 4. (a) Overall top 19 most effective risks, (b) Top 10 risks for cost objective.

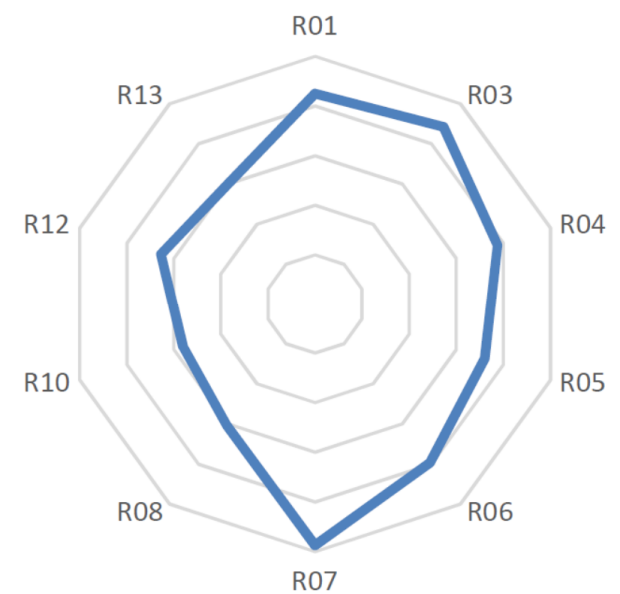

(a)

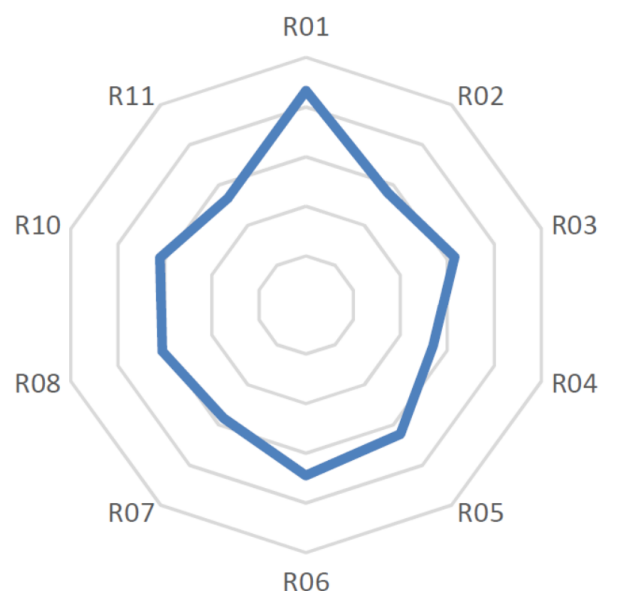

(b)

Figure 5. (a) Top 10 risks for time objective, (b) Top 10 risks for quality objective.

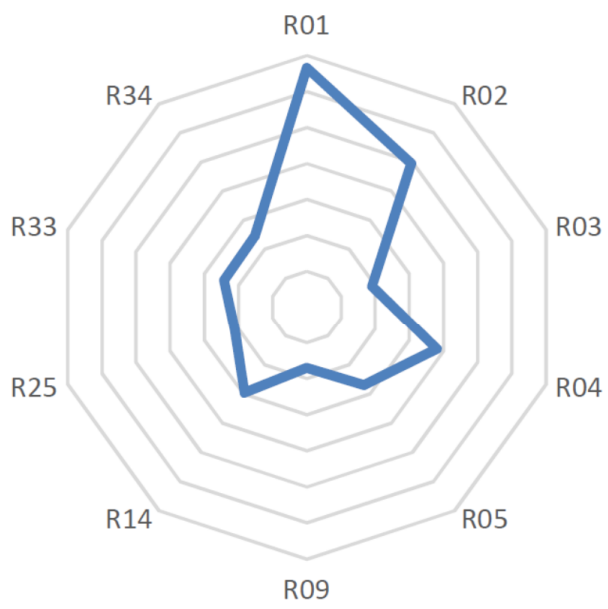

(a)

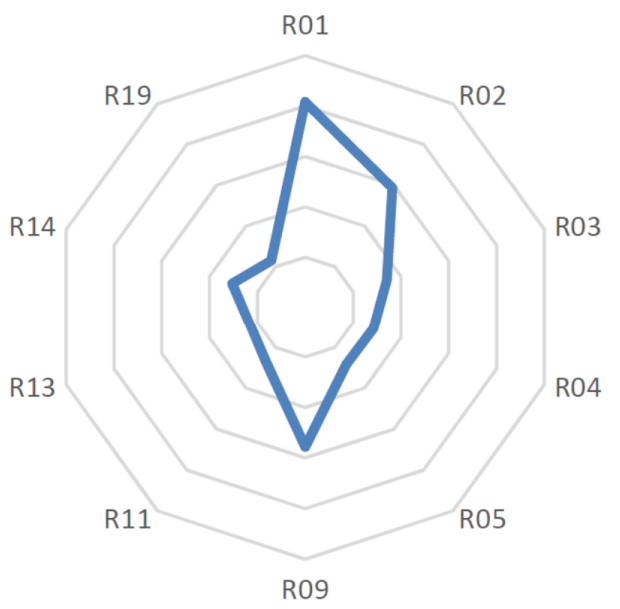

(b)

Figure 6. (a) Top 10 risks for environment objective, (b) Top 10 risks for for safety objective. 


\subsection{Weighting of Identified Drilling Risks Using BWM Method}

In the next step and to calculate the weight of each risk on project contract selection the BWM was adapted from [55] and was employed in accordance with the following procedure:

1. Considering the high importance risks as the set of decision criteria $\left\{R_{1}, R_{2}, \ldots, R_{n}\right\}$ by decision-makers.

2. Determining the best and the worst criteria to be used for the decision environment. This step generally is done by choosing the best and the worst criteria among the set of criteria identified in Step 1 from the perspective of decision-makers. The best criteria represent the most important criteria and the worst criteria are the least important criteria for the decision. This step in the current study has been completed in the previous stage and the importance of the criteria has been determined already. The Blow out contingency (R1) and the Changing social responsibility rules and regulations (R35) have been considered as the best criterion and the worst criterion, respectively.

3. Determining the preference of the best criteria over all the other criteria: A number between 1 and 9 (1: equally important, 9: extremely more important) is used to indicate this value. The resulting Best-to-Others vector would be as $A_{B}=\left(a_{B 1}, a_{B 2}, \ldots, a_{B n}\right)$, where $a_{B j}$ indicates the preference of criteria B (best criteria) over criteria j and $a_{B B}=1$. Using the BWM questionnaire, experts were asked to compare R1 with each of the other criteria and to express their preference using a value between 1 and 9 . Then, by calculating the geometric mean of the four questionnaires, aggregated Best-to-Others (BO) was constructed, as shown in Table 4.

4. Determining the preference of each of the other criteria over the worst criteria: A number between 1 and 9 was assigned to this case as well. The Others-to-Worst vector would be $A_{w}=\left(a_{1 w}, a_{2 w}, \ldots, a_{n w}\right)^{T}$, where $a_{j w}$ indicates the preference of the criteria $j$ over the worst criteria $W$ and $a_{w w}=1$. Similarly to the previous step, the experts were then asked to express their preferences of all other criteria over the least important criterion of R35. As in the previous step, a value between 1 and 9 was used to determine the preferences. Then, by calculating the geometric mean, the aggregated Others-to-Worst (OW) vector was constructed as shown in Table 5.

5. Find the optimal weights $\left(w_{1}^{*}, w_{2}^{*}, \ldots, w_{n}^{*}\right)$ : Solving the problem (1) will result in the optimal weights for the criteria. To determine the optimal weights of the criteria, the maximum absolute differences $\left|\frac{w_{B}}{w_{j}}-a_{B j}\right|$ and $\left|\frac{w_{j}}{w_{w}}-a_{j w}\right|$ for all $\mathrm{j}$ should be minimized.

$$
\begin{gathered}
\operatorname{minmax}_{\mathrm{j}}\left\{\left|\frac{\mathrm{w}_{\mathrm{B}}}{\mathrm{w}_{\mathrm{j}}}-\mathrm{a}_{\mathrm{Bj}}\right|,\left|\frac{\mathrm{w}_{\mathrm{j}}}{\mathrm{w}_{\mathrm{w}}}-\mathrm{a}_{\mathrm{jw}}\right|\right\} \\
\text { s.t. } \\
\sum_{\mathrm{j}} \mathrm{w}_{\mathrm{j}}=1 \\
w_{j} \geq 1, \text { for all } j
\end{gathered}
$$

\begin{tabular}{|c|c|c|c|c|c|c|c|c|c|c|c|c|c|c|c|c|c|c|c|c|c|c|c|c|c|c|c|c|c|c|c|c|c|c|}
\hline $\begin{array}{c}\text { Best } \\
\text { Criterion. }\end{array}$ & 元 & స & ప & $\underset{\Delta}{\pi}$ & ত & ส & तु & $\underset{\infty}{\mathbb{\infty}}$ & $\pi$ & 元 & & 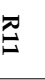 & 荧 & $\underset{\omega}{\pi}$ & $\underset{\mathbb{E}}{\overparen{Z}}$ & 忢 & 萦 & $\stackrel{\pi}{\vec{v}}$ & $\underset{\infty}{\underset{\infty}{\pi}}$ & $\underset{\sigma}{\pi}$ & 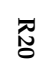 & 胥 & 胥 & స్ల్ర & 趈 & 总 & 胥 & 胥 & $\underset{\infty}{\mathbb{N}}$ & 胥 & 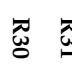 & 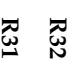 & : & 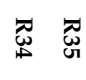 \\
\hline$R 1$ & $\checkmark$ & $\infty$ & $v$ & $G$ & $\omega$ & $\sigma$ & 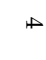 & G & $\sigma$ & 10 & $\pi$ & $a$ & $\stackrel{\leftrightarrow}{\omega}$ & $\dot{6}$ & $\stackrel{g}{v}$ & $\omega$ & $\underset{\infty}{\infty}$ & $\stackrel{\infty}{i}$ & $\stackrel{\infty}{v}$ & $\stackrel{n}{\dot{v}}$ & $\stackrel{N}{N}$ & $\overrightarrow{6}$ & $\stackrel{\sim}{i}$ & $\stackrel{p}{i}$ & G & $\dot{i}$ & $\underset{\omega}{\omega}$ & $\vec{b}$ & $\vdash$ & $\stackrel{N}{\infty}$ & $a$ i & טै & $\begin{array}{ll}v \\
0\end{array}$ & $\begin{array}{ll}\infty & \infty \\
\text { ir } & \text { i }\end{array}$ \\
\hline
\end{tabular}

Table 4. Criteria Best-to-Others (BO) Vector. 
Table 5. Criteria for Others-to-Worst (OW) Vector.

\begin{tabular}{|c|c|c|c|c|c|c|c|c|c|c|c|c|c|c|c|c|c|c|c|c|c|c|c|c|c|c|c|c|c|c|c|c|c|c|}
\hline $\begin{array}{l}\text { Worst } \\
\text { Criterion. }\end{array}$ & 지 & 忩 & $\underset{\omega}{\varpi}$ & $\ddot{\mathbb{A}}$ & 元 & $\approx$ & 刃্ত & $\underset{\infty}{\approx}$ & $\pi$ & ত্ّة & 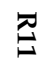 & 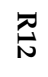 & $\underset{\omega}{\pi}$ & $\underset{D}{\pi}$ & 元 & 面 & $\underset{⿱ ⺌}{\vec{v}}$ & $\underset{\infty}{\pi}$ & ত্র & 정 & 忑 & 贫 & $\underset{\omega}{\mathbb{\omega}}$ & $\underset{⿱ 亠 凶}{\mathbb{N}}$ & స్心 & సু & 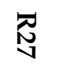 & $\underset{\infty}{\mathbb{N}}$ & స్త్ర & స్ర్ర & 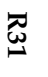 & $\underset{N}{\mathbb{N}}$ & స్ట్ర & 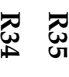 \\
\hline R35 & $\underset{\infty}{\infty}$ & تَ & ¿v & i- & à & ت & $\checkmark$ & ă & $\stackrel{+}{\sigma}$ & $\tilde{\omega}$ & $\underset{i}{\dot{i}}$ & $\stackrel{a}{i}$ & 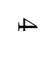 & $\stackrel{+}{\dot{*}}$ & $\dot{\omega}$ & $\bullet$ & 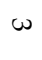 & $i$ & $i$ & $\begin{array}{l}\infty \\
\dot{\omega}\end{array}$ & $\dot{a}$ & $\begin{array}{l}\infty \\
\dot{\omega}\end{array}$ & $\stackrel{\text { v }}{ }$ & $\underset{i}{G}$ & $\stackrel{\infty}{\infty}$ & is & $\underset{\infty}{\sigma}$ & $\infty$ & $\stackrel{\infty}{\infty}$ & $\stackrel{\bullet}{6}$ & $\hat{\sigma}$ & $\underset{\sim}{\omega}$ & & \begin{tabular}{lll}
$n$ \\
\hdashline
\end{tabular} \\
\hline
\end{tabular}

This model can be solved by transferring it to the linear programming (2) [41]:

$$
\begin{gathered}
\min \xi \\
\text { s.t. } \\
\left|\frac{w_{B}}{w_{j}}-a_{B j}\right| \leq \xi \text { for all } j \\
\frac{w_{j}}{w_{w}}-a_{j w} \mid \leq \xi \text { for all } j \\
\sum_{j} w_{j}=1 \\
w_{j} \geq 0, \text { for all } j
\end{gathered}
$$

By solving this problem, the optimal weights $\left(w_{1}^{*}, w_{2}^{*}, \ldots, w_{n}^{*}\right)$ and the optimal value of $\xi^{*}$ are obtained. $\xi^{*}$ can be defined as the consistency ratio of the comparison system. It means that the closer $\xi^{*}$ is to zero, the more consistent the comparison system is provided by the decision makers. The Equation (2) was used to check the consistency of the comparisons [56].

$$
\text { Consistency Ratio }=\frac{\xi^{*}}{\text { Consistency Index }} .
$$

The consistency index can be retrieved from Table 6. In this table, the lower the consistency ratio, the higher the reliability of the comparisons. As can be inferred from Table 2, in this case, "Blow out contingency", "Tight hole of the well and casing run problems", and "Pipe failure" are the most important drilling risks and "Disposal and discharge of wastewater and drilling fluid", "Lack of sufficient knowledge and information of field and reservoir structures", and "Changing social responsibility rules and regulations" are the least important drilling risks, respectively. As shown in Table 7, the comparisons show a high consistency as the value of consistency ratio of criteria is close to zero (the

\begin{tabular}{|c|c|c|c|c|c|c|c|c|c|c|c|c|c|c|c|c|c|c|c|c|c|c|c|c|c|c|c|c|c|c|c|c|c|c|}
\hline Criteria. & 元 & & $\underset{\omega}{\not}$ & 五 & ত & $\approx$ & 刃্ত & $\underset{\infty}{\approx}$ & $\pi$ & $\underset{\sigma}{0}$ & 元 & $\underset{N}{\pi}$ & $\underset{\omega}{\varpi}$ & $\underset{\infty}{\overparen{D}}$ & 坣 & 鬲 & $\underset{⿱ ⺌}{\nabla}$ & $\underset{\infty}{\infty}$ & ప & S & స్N & స్心 & 芯 & 忑 & స్রু & ত্র & $\underset{\infty}{\mathbb{N}}$ & 胥 & $\underset{\mathscr{\sigma}}{\widetilde{\Xi}}$ & $\underset{\omega}{\varpi}$ & 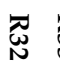 & $\underset{\omega}{\varpi ్}$ & $\underset{\perp}{\underset{\perp}{~}}$ & $\underset{\widetilde{\omega}}{\widetilde{\omega}}$ \\
\hline Weight & 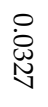 & $\begin{array}{l}0 \\
\dot{0} \\
\text { స్ర }\end{array}$ & $\begin{array}{l}\stackrel{\circ}{\dot{\omega}} \\
\stackrel{\dot{\omega}}{N}\end{array}$ & $\begin{array}{l}0 \\
\dot{8} \\
\dot{d} \\
\text { v }\end{array}$ & $\stackrel{\circ}{\stackrel{\ominus}{\mathcal{W}}}$ & 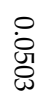 & 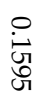 & 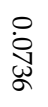 & $\begin{array}{l}\circ \\
\text { Oे } \\
\text { 克 } \\
\perp\end{array}$ & $\begin{array}{l}\circ \\
\dot{0} \\
\text { N్ }\end{array}$ & $\begin{array}{l}\stackrel{\circ}{0} \\
\stackrel{్}{W} \\
\stackrel{\infty}{N}\end{array}$ & $\begin{array}{l}\stackrel{\circ}{\sigma} \\
\stackrel{\sigma}{\sigma}\end{array}$ & $\begin{array}{l}\circ \\
\dot{\mathscr{W}} \\
\stackrel{్}{N}\end{array}$ & $\begin{array}{l}\stackrel{\circ}{0} \\
\dot{\phi} \\
\stackrel{6}{6}\end{array}$ & 㝘 & $\begin{array}{l}\stackrel{\circ}{0} \\
\dot{\omega} \\
\stackrel{\omega}{\omega}\end{array}$ & 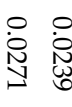 & 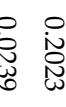 & 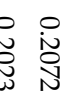 & D & 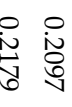 & $\begin{array}{l}\stackrel{\circ}{\Delta} \\
\stackrel{\Sigma}{\infty}\end{array}$ & 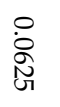 & $\begin{array}{l}\circ \\
\dot{0} \\
\stackrel{d}{d} \\
\infty\end{array}$ & 猋 & 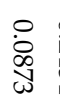 & $\begin{array}{l}\circ \\
\stackrel{N}{N} \\
\text { 点 }\end{array}$ & $\begin{array}{l}\stackrel{\circ}{\dot{D}} \\
\stackrel{\infty}{\omega}\end{array}$ & $\begin{array}{l}\circ \\
\stackrel{\circ}{0} \\
\stackrel{\leftrightarrow}{0}\end{array}$ & 葛 & $\begin{array}{l}\circ \\
\dot{0} \\
\infty \\
\infty \\
\infty\end{array}$ & $\begin{array}{l}\circ \\
\dot{D} \\
\stackrel{d}{0}\end{array}$ & $\begin{array}{l}\circ \\
\dot{\mathcal{N}} \\
\text { 促 }\end{array}$ & 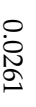 \\
\hline Rank & 26 & 28 & 27 & 14 & 7 & 19 & 10 & 16 & 22 & 18 & 23 & 13 & 25 & 24 & 9 & 35 & 313 & 345 & $5 \quad 4$ & 42 & 23 & 12 & 17 & 21 & 8 & 15 & 1 & 6 & 20 & 11 & 30 & 29 & 33 & 32 \\
\hline$\xi^{*}$ & \multicolumn{34}{|c|}{0.98356948} \\
\hline $\begin{array}{l}\text { Consistency } \\
\text { Ratio }\end{array}$ & \multicolumn{34}{|c|}{0.18} \\
\hline
\end{tabular}
consistency ratio for criteria comparisons is 0.18 ).

Table 6. Consistency index.

\begin{tabular}{cccccccccc}
\hline $\boldsymbol{a}_{\boldsymbol{B W}}$ & $\mathbf{1}$ & $\mathbf{2}$ & $\mathbf{3}$ & $\mathbf{4}$ & $\mathbf{5}$ & $\mathbf{6}$ & $\mathbf{7}$ & $\mathbf{8}$ & $\mathbf{9}$ \\
\hline Consistency index & 0.00 & 0.44 & 1.00 & 1.63 & 2.30 & 3.00 & 3.73 & 4.47 & 5.23 \\
\hline
\end{tabular}

Table 7. The risks' weights. 


\subsection{Prioritize Contract Alternatives Using the AHP Method}

The purpose of this paper was to propose a model for selecting the most appropriate drilling contract based on risk analysis. Therefore, three models of the most common contracts of the onshore drilling industry were selected through expert opinions. Day-rate contract, Footage contract, and Turnkey contract options were described in detail in the literature review. As discussed earlier, they can be combined with incentive mechanisms, therefore there are six different contract alternatives. Given the impact of risk on project objectives (cost, time, quality, safety and environment), these calculations were performed by looking at overall impacts. In order to prioritize these contracts, the AHP method was used, which is explained below.

\subsubsection{Development of the AHP Model}

The design of the AHP hierarchy must satisfy the goal of developing a model that will allow operators or contractors to decide which drilling contract is more appropriate for their particular situation. The hierarchy developed in this study consists of three levels. The top level represents the goal of selecting the best onshore drilling contract. The last level is represented by the six alternative drilling contracts. The second level is the decision criteria that include 35 drilling risks in this article.

\subsubsection{Determining the Comparison Matrix}

Once the hierarchy was established, the pairwise comparison evaluation took place. The use of this AHP model requires the expert's judgment to discuss and determine the relative importance of each of the elements in the hierarchy. Each element in the third level (Drilling Contracts) was compared pair-wise with other elements at the same level, with respect to a criterion element. The pair-wise comparison was based on a scale of 1 to 9 as per the definition of weights given in Table 2. Table 8 shows a schematic matrix of pairwise comparisons of alternatives which was done for each criterion using Expert Choice software (V11.0, Expert Choice Inc., Arlington, USA).

Table 8. Pair-wise comparison matrix for six alternatives.

\begin{tabular}{|c|c|c|c|c|c|c|}
\hline $\begin{array}{c}\text { Pair-Wise } \\
\text { Comparison Matrix } \\
\text { for R1 Criterion }\end{array}$ & Day-Rate (X1) & Footage (X2) & Turnkey (X3) & $\begin{array}{c}\text { Day-Rate } \\
\text { Incentive (X4) }\end{array}$ & $\begin{array}{c}\text { Footage } \\
\text { Incentive (X5) }\end{array}$ & $\begin{array}{c}\text { Turnkey } \\
\text { Incentive (X6) }\end{array}$ \\
\hline Day-rate $(X 1)$ & 1 & $\mathrm{a}$ & $\mathrm{b}$ & c & $\mathrm{d}$ & e \\
\hline Footage $(X 2)$ & $1 / a$ & $\mathrm{f}$ & $\mathrm{g}$ & $\mathrm{h}$ & $\mathrm{i}$ & j \\
\hline Turnkey (X3) & $1 / b$ & $1 / \mathrm{g}$ & 1 & k & 1 & $\mathrm{~m}$ \\
\hline $\begin{array}{c}\text { Day-rate } \\
\text { Incentive }(X 4)\end{array}$ & $1 / \mathrm{c}$ & $1 / \mathrm{h}$ & $1 / \mathrm{k}$ & 1 & $\mathrm{n}$ & o \\
\hline $\begin{array}{c}\text { Footage } \\
\text { Incentive (X5) }\end{array}$ & $1 / d$ & $1 / \mathrm{i}$ & $1 / 1$ & $1 / \mathrm{n}$ & 1 & $\mathrm{p}$ \\
\hline $\begin{array}{c}\text { Turnkey } \\
\text { Incentive (X6) }\end{array}$ & $1 / \mathrm{e}$ & $1 / j$ & $1 / \mathrm{m}$ & $1 / o$ & $1 / \mathrm{p}$ & 1 \\
\hline
\end{tabular}

\subsection{Relative Weight and Priority Evaluation}

According to the results of pair-wise comparisons and data entry in Expert Choice software, the relative weight of each contract for each criterion against the cost target was calculated. The crossing product of all project evaluations using all criteria determined the final priority for each contract in relation to the desired goal. The mechanism for calculating the final priority was to sum the products of the multiplication of each criterion's priority weight by its alternative weight. The same process should be repeated for all six contracts. The final results for all contracts are shown in Table 9. 
Table 9. Priority results for the drilling contracts according to the drilling risks.

\begin{tabular}{ccc}
\hline Alternative Code. & Contract Type & Final Normalized Score \\
\hline X1 & Day-rate & 0.65 \\
\hline X2 & Footage & 0.59 \\
\hline X3 & Turnkey & 0.71 \\
\hline X4 & Day-rate Incentive & 0.69 \\
\hline X5 & Footage Incentive & 0.86 \\
\hline X6 & Turnkey Incentive & 0.78 \\
\hline
\end{tabular}

\section{Discussion and Practical Implications}

Construction contracts are one of the most crucial factors to address the challenging problem of risk management of a project. Hence project contract strategy and selection regarding the risks of a project can have a considerable impact on project success. Risks, which is defined as an uncertain event or condition that could occur, have an effect on project objectives [57], is an inevitable attribute of construction projects and actually the costs of them will be carried by the party who is determined to do so in the contract. The risks in construction projects can influence project key performance indices and basic objectives of time, cost, scope, and quality [58]. Project risk management has a significant impact on project performance because recognizing and handling the uncertainties majorly increases productivity in terms of cost, time, scope, quality, environment, and the other factors. Based on the proposed model in this research, impacts of risks on five different project objectives were assessed for selection of the most appropriate contract strategy. To this purpose, a WBM-based AHP system was developed in the context of the drilling projects. Firstly and based on a case, the recognized risks in the form of RBS were analyzed and the most effective (Blow out contingency (R1)) and the least effective (Changing social responsibility rules and regulations (R35)) ones were determined. These factors in the BWM were labeled as the best criterion and the worst criterion. However, based on a pair-wise comparison of available contract strategies as different alternatives, a "Footage Incentive" option was determined as the most appropriate contract strategy for drilling projects in Iran with the 8 dominant characteristics mentioned in Section 4.1. Reviewing the documents of the previous successful drilling projects in Iran, which have been implemented in the oil fields with the above mentioned features, shows that the results of the presented model, i.e., selection of the Incentive and Turnkey contract types, to an acceptable extent are consistent with the methods which are used in the industry. Since the presented RBS is a generic list of risks, the developed model can be adapted for contract selection of drilling projects in the oil or even gas fields with different characteristics. Therefore, the first party of drilling projects i.e., the client or her/his agent company can employ the presented systematic model to solve the project contract strategy selection problem. The main limitations of the current study were the lack of comprehensive references who address the risks of drilling projects and also the scientific approach for oil fields categorization and description of their contracts.

\section{Conclusions}

In this study, a novel approach has been introduced to solve the contract selection problem in the context of the drilling projects. The major contribution of this study can be divided into two parts: development of a generic list of prospective risks in a structured form named RBS. Also, proposing a risk-BWM Based model to solve the original problem of contract selection. Although the presented RBS has been developed for onshore drilling projects, it can be adapted for a wide range of underground drilling projects including offshore efforts and geothermal activities. The comprehensive RBS include four levels: one heading in level 0, eight main areas of risk in level 1, 34 sub-areas of risk in level 2, and finally 217 risk items in level 3 . The above RBS have been formed in a bottom-up 
method; firstly the 122 relevant risks in previous research were gathered and then they were purified and completed using the Delphi method. In the next step, the recognized risks were ranked considering their impact on project objectives and finally they were used to solve the contract selection problem through BWM. However, converting the risk items into decision criteria through assessment of their probable impact on project objectives can open up new horizons in decision making area in the early phases. Therefore, a decision making model was proposed for the determination of a contract strategy which itself is considered as one of the most significant parameters that affects a project's success. It is worth mentioning that it is crucial to select the most appropriate contract type in the pre-project planning phase, especially in drilling activities which are considered as high cost projects in the upstream sector of the petroleum industry.

Author Contributions: Conceptualization, A.F.; methodology, A.F., M.R., and S.P.; validation, A.F., M.R. and P.K.; investigation, A.F.; resources, P.K.; writing-original draft preparation, A.F.; writingreview and editing, A.F., P.K., and S.P.; supervision, M.R.; project administration, M.R. All authors have read and agreed to the published version of the manuscript.

Funding: This research received no internal or external funding from any commercial or noncommercial source.

Institutional Review Board Statement: Not applicable.

Informed Consent Statement: Not applicable.

Data Availability Statement: All data is contained within the article.

Conflicts of Interest: The authors declare no conflict of interest.

\section{Appendix A}

Table A1. Risk breakdown structure of drilling projects.

\begin{tabular}{|c|c|c|c|c|c|}
\hline RBS Level 0 & RBS Level 1 & RBS Level 2 & RBS Level 3 & References & RBS Code \\
\hline \multirow{11}{*}{$\begin{array}{l}\text { Onshore } \\
\text { Drilling Risk }\end{array}$} & \multirow{11}{*}{$\begin{array}{l}\text { Organizational/ } \\
\text { Managerial Risk }\end{array}$} & \multirow{5}{*}{ Organization } & $\begin{array}{l}\text { Inadequate project } \\
\text { organization Structure }\end{array}$ & {$[40]$} & 1101 \\
\hline & & & $\begin{array}{l}\text { Change of organization ownership } \\
\text { or management }\end{array}$ & [59] & 1102 \\
\hline & & & Improper project feasibility study & [40] & 1103 \\
\hline & & & $\begin{array}{l}\text { Lack of proper data bank for accidents/ } \\
\text { keeping the accident data secret }\end{array}$ & [60] & 1104 \\
\hline & & & $\begin{array}{l}\text { Lack of sufficient resources to } \\
\text { improve HSE }\end{array}$ & {$[60]$} & 1105 \\
\hline & & \multirow{6}{*}{ Project } & $\begin{array}{l}\text { Bureaucratic government system and } \\
\text { long project approval procedure }\end{array}$ & [40] & 1201 \\
\hline & & & $\begin{array}{l}\text { Late internal approval process from } \\
\text { the owner }\end{array}$ & [40] & 1202 \\
\hline & & & $\begin{array}{l}\text { Unclear and imprecise delegation of } \\
\text { responsibilities and roles and } \\
\text { project charter }\end{array}$ & {$[61]$} & 1203 \\
\hline & & & Changes in the scope of the project & Survey & 1204 \\
\hline & & & Failure to achieve the main target point & [62] & 1205 \\
\hline & & & $\begin{array}{l}\text { Lack of proper written work procedures } \\
\text { and instructions }\end{array}$ & {$[60]$} & 1206 \\
\hline
\end{tabular}


Table A1. Cont.

\begin{tabular}{|c|c|c|c|c|c|}
\hline RBS Level 0 & RBS Level 1 & RBS Level 2 & RBS Level 3 & References & RBS Code \\
\hline & & \multirow{3}{*}{ Planning } & $\begin{array}{l}\text { Weakness in planning and scheduling } \\
\text { and initial project resources }\end{array}$ & [63] & 1301 \\
\hline & & & $\begin{array}{l}\text { Improper project planning and } \\
\text { Budgeting and lack of accurate } \\
\text { estimation of project value }\end{array}$ & [40] & 1302 \\
\hline & & & Lack of emergency response plan & [60] & 1303 \\
\hline & & \multirow{3}{*}{ Design } & Poor design & [64] & 1401 \\
\hline & & & Design changes & {$[65]$} & 1402 \\
\hline & & & $\begin{array}{l}\text { Late changes to well design } \\
\text { and procedures }\end{array}$ & [35] & 1403 \\
\hline & & \multirow{3}{*}{ Implementation } & $\begin{array}{l}\text { Inappropriate choice of project } \\
\text { implementation method }\end{array}$ & [62] & 1501 \\
\hline & & & $\begin{array}{l}\text { Failure to predict the exact time to run } \\
\text { the project }\end{array}$ & [62] & 1502 \\
\hline & & & $\begin{array}{l}\text { Failure to select the type of } \\
\text { implementation or project contract } \\
\text { according to the conditions }\end{array}$ & Survey & 1503 \\
\hline & & \multirow{6}{*}{ Project team } & Incompetence of project team & [40] & 1601 \\
\hline & & & $\begin{array}{l}\text { Inefficiency or inexperience of the } \\
\text { project team }\end{array}$ & & 1602 \\
\hline & & & Contractor's error & {$[66]$} & 1603 \\
\hline & & & Making the wrong decisions & Survey & 1604 \\
\hline & & & $\begin{array}{l}\text { Inefficient and poor performance } \\
\text { of Constructors }\end{array}$ & [40] & 1605 \\
\hline & & & $\begin{array}{l}\text { Excessive delays due to late decisions } \\
\text { making by project participants }\end{array}$ & Survey & 1606 \\
\hline & & \multirow{4}{*}{ Management } & Incompetence of project manager & [67] & 1701 \\
\hline & & & $\begin{array}{l}\text { Lack of meritocracy (in recruiting, } \\
\text { organizing and promoting staff) }\end{array}$ & [60] & 1702 \\
\hline & & & $\begin{array}{l}\text { Incompetence of managers, supervisors } \\
\text { and HSE crew }\end{array}$ & {$[60]$} & 1703 \\
\hline & & & $\begin{array}{l}\text { Lack of support from executives and } \\
\text { senior management }\end{array}$ & Survey & 174 \\
\hline & & \multirow{7}{*}{$\begin{array}{l}\text { Human } \\
\text { element }\end{array}$} & $\begin{array}{l}\text { Lack of skills of drilling staff } \\
\text { (inadequate practice of skills) }\end{array}$ & [68] & 1801 \\
\hline & & & Lack of effective trainings & [32] & 1802 \\
\hline & & & $\begin{array}{l}\text { There is poor relationship between } \\
\text { personnel and superiors }\end{array}$ & [32] & 1803 \\
\hline & & & $\begin{array}{l}\text { Inexperienced and less } \\
\text { knowledgeable personnel }\end{array}$ & [59] & 1804 \\
\hline & & & Unmotivated personnel & [3] & 1805 \\
\hline & & & High stress and work pressure & [68] & 1806 \\
\hline & & & $\begin{array}{l}\text { The number of workers in workplace is } \\
\text { not appropriate for the job (more or less) }\end{array}$ & [32] & 1807 \\
\hline
\end{tabular}


Table A1. Cont.

\begin{tabular}{|c|c|c|c|c|c|}
\hline RBS Level 0 & RBS Level 1 & RBS Level 2 & RBS Level 3 & References & RBS Code \\
\hline & & & $\begin{array}{l}\text { The worker is injured or sick } \\
\text { (temporarily, e.g., because of a flu) }\end{array}$ & [32] & 1808 \\
\hline & & & $\begin{array}{l}\text { Ergonomic problems due to fatigue and } \\
\text { pressure of non-stop activities }\end{array}$ & [62] & 1809 \\
\hline & & & Inadequacy of specialized personnel & Survey & 1810 \\
\hline & \multirow{9}{*}{ Contractual Risk } & \multirow{7}{*}{ Contract } & Inappropriate contracts & Survey & 2101 \\
\hline & & & Ambiguous conditions of contract & [40] & 2102 \\
\hline & & & $\begin{array}{l}\text { Improper verification of } \\
\text { contract documents }\end{array}$ & [3] & 2103 \\
\hline & & & Work conditions deferring from contract & [40] & 2104 \\
\hline & & & Changes on scope of contract & [59] & 2105 \\
\hline & & & $\begin{array}{l}\text { Unballance share of legal risks between } \\
\text { the parties }\end{array}$ & Survey & 2106 \\
\hline & & & Contractual liability failure & Survey & 2107 \\
\hline & & \multirow{2}{*}{$\begin{array}{l}\text { Type and terms } \\
\text { of contract }\end{array}$} & Unclear Contractual requirements & Survey & 2201 \\
\hline & & & $\begin{array}{l}\text { Changes in contract related rules } \\
\text { and regulations }\end{array}$ & Survey & 2202 \\
\hline & \multirow{15}{*}{ Economic Risk } & \multirow{10}{*}{$\begin{array}{c}\text { Economic } \\
\text { Changes and } \\
\text { fluctuations }\end{array}$} & Changes in supply and demand & [63] & 3101 \\
\hline & & & Changes in tax policy and tax rates & [63] & 3102 \\
\hline & & & Oil price fluctuations & [65] & 3103 \\
\hline & & & Exchange rate changes & [40] & 3104 \\
\hline & & & Interest rate fluctuation & [40] & 3105 \\
\hline & & & Inflation rate fluctuation & [40] & 3106 \\
\hline & & & $\begin{array}{l}\text { Instability of economic indicators of the } \\
\text { host country }\end{array}$ & Survey & 3107 \\
\hline & & & Increase of material cost & {$[40]$} & 3108 \\
\hline & & & Increase of labor cost & {$[40]$} & 3109 \\
\hline & & & Price instability of fuel and steel & [3] & 3110 \\
\hline & & \multirow{5}{*}{ Financial risk } & Deficiency in Provide project funds & Survey & 3201 \\
\hline & & & $\begin{array}{l}\text { Increase the cost of materials } \\
\text { and personnel }\end{array}$ & Survey & 3202 \\
\hline & & & $\begin{array}{l}\text { Improper cost calculations for } \\
\text { the investment }\end{array}$ & [66] & 3203 \\
\hline & & & $\begin{array}{l}\text { Delayed disbursement of funds } \\
\text { from financiers }\end{array}$ & [3] & 3204 \\
\hline & & & Lack of economic production & Survey & 3205 \\
\hline & \multirow{5}{*}{ Political / Social Risk } & \multirow{5}{*}{ Government } & Confiscation and nationalization & Survey & 4101 \\
\hline & & & Expropriation & Survey & 4102 \\
\hline & & & $\begin{array}{l}\text { Change in contract provisions by } \\
\text { the government }\end{array}$ & [63] & 4103 \\
\hline & & & $\begin{array}{l}\text { Reduction in annual budget allocation } \\
\text { by government }\end{array}$ & [3] & 4104 \\
\hline & & & Changes in foreign investment laws & Survey & 4105 \\
\hline
\end{tabular}


Table A1. Cont.

\begin{tabular}{|c|c|c|c|c|c|}
\hline RBS Level 0 & RBS Level 1 & RBS Level 2 & RBS Level 3 & References & RBS Code \\
\hline & & & $\begin{array}{l}\text { Customs restrictions or the export and } \\
\text { import of goods }\end{array}$ & Survey & 4106 \\
\hline & & & Change in rules and regulations & [67] & 4107 \\
\hline & & & $\begin{array}{l}\text { Loss incurred due to corruption } \\
\text { and bribery }\end{array}$ & [3] & 4108 \\
\hline & & \multirow{5}{*}{$\begin{array}{l}\text { The state of the } \\
\text { host country }\end{array}$} & Rebellion & Survey & 4201 \\
\hline & & & War/Vandalism & [64] & 4202 \\
\hline & & & Terrorism & Survey & 4203 \\
\hline & & & Political instability of the host country & Survey & 4204 \\
\hline & & & Sanctions and special bans & Survey & 4205 \\
\hline & & \multirow{7}{*}{ Social Hazards } & Sabotage measures & Survey & 4301 \\
\hline & & & Lack of acceptance in local communities & Survey & 4302 \\
\hline & & & $\begin{array}{l}\text { Changing social responsibility rules } \\
\text { and regulations }\end{array}$ & Survey & 4303 \\
\hline & & & $\begin{array}{l}\text { Negative attitude towards local oil and } \\
\text { gas multinational companies }\end{array}$ & Survey & 4304 \\
\hline & & & Changes in consumer demands & Survey & 4305 \\
\hline & & & Workers' strikes & Survey & 4306 \\
\hline & & & Dispute with residents around site & [40] & 4307 \\
\hline & \multirow{13}{*}{ Geological Risk } & \multirow{5}{*}{$\begin{array}{l}\text { Geological } \\
\text { structure }\end{array}$} & $\begin{array}{l}\text { Geological structure and complexity of } \\
\text { the region }\end{array}$ & [65] & 5101 \\
\hline & & & Geological Faults and Structures & [69] & 5102 \\
\hline & & & Abnormal pressured zone & {$[64]$} & 5103 \\
\hline & & & Unexpected natural subsurface obstacles & {$[62]$} & 5104 \\
\hline & & & Man-made subsurface obstacles & {$[62]$} & 5105 \\
\hline & & & Lack of full knowledge of the field & Survey & 5201 \\
\hline & & Geological & $\begin{array}{l}\text { Lack of sufficient knowledge and } \\
\text { information of field and } \\
\text { reservoir structures }\end{array}$ & Survey & 5202 \\
\hline & & information & $\begin{array}{l}\text { Lack of accurate information on the } \\
\text { structure and volume of the reservoir }\end{array}$ & Survey & 5203 \\
\hline & & & $\begin{array}{l}\text { Lack of accurate information on the } \\
\text { fluid properties of the tank and how it is } \\
\text { distributed in the tank }\end{array}$ & Survey & 5204 \\
\hline & & & $\begin{array}{l}\text { Different behavior of geological } \\
\text { formations in different wells }\end{array}$ & Survey & 5301 \\
\hline & & Formation & Displacement of formations & Survey & 5302 \\
\hline & & & Formation pressure & [35] & 5303 \\
\hline & & & Total/partial losses in formation layers & [62] & 5304 \\
\hline & Operational Risk & Well casing & $\begin{array}{l}\text { Lack of well rehabilitation before casing } \\
\text { running operations and the } \\
\text { resulting problems }\end{array}$ & Survey & 6101 \\
\hline & & & $\begin{array}{l}\text { Problems with Reamer running into a } \\
\text { well, such as Fishing or falling its rollers }\end{array}$ & Survey & 6102 \\
\hline
\end{tabular}


Table A1. Cont.

\begin{tabular}{|c|c|c|c|c|c|}
\hline RBS Level 0 & RBS Level 1 & RBS Level 2 & RBS Level 3 & References & RBS Code \\
\hline & & & $\begin{array}{l}\text { Problem in Shoe and its installation and } \\
\text { disruption in casing running }\end{array}$ & Survey & 6103 \\
\hline & & & Float Shoe plaque while casing running & Survey & 6104 \\
\hline & & & $\begin{array}{l}\text { Damage to casing in the operational } \\
\text { area, especially their threads due to } \\
\text { incorrect transmission conditions }\end{array}$ & Survey & 6105 \\
\hline & & & $\begin{array}{l}\text { Changes in the size of the inner } \\
\text { diameter of the casing in some parts due } \\
\text { to impact }\end{array}$ & Survey & 6106 \\
\hline & & & $\begin{array}{l}\text { Lack of wrenches and tools suitable for } \\
\text { casing running }\end{array}$ & Survey & 6107 \\
\hline & & & $\begin{array}{l}\text { Centralizers break during casing and } \\
\text { liner running }\end{array}$ & Survey & 6108 \\
\hline & & & $\begin{array}{l}\text { Tight hole of the well and casing } \\
\text { run problems }\end{array}$ & Survey & 6109 \\
\hline & & & $\begin{array}{l}\text { Problems with not installing Cager } \\
\text { Hanger properly }\end{array}$ & Survey & 6110 \\
\hline & & & $\begin{array}{l}\text { Liner Lap leak and perform Seal Nipple } \\
\text { Packer operation }\end{array}$ & Survey & 6111 \\
\hline & & & Seal Nipple Packer leak if used & Survey & 6112 \\
\hline & & & $\begin{array}{l}\text { Casing corrosion and } \mathrm{H} 2 \mathrm{~s} \text { migration } \\
\text { to annulus }\end{array}$ & Survey & 6113 \\
\hline & & & $\begin{array}{l}\text { Casing Head Housing is not aligned for } \\
\text { various reasons such as welding error } \\
\text { and causing problems in the next phases } \\
\text { of operation and installation BOPs }\end{array}$ & Survey & 6114 \\
\hline & & \multirow{13}{*}{ Pipelines } & Pipe failure & {$[70]$} & 6201 \\
\hline & & & Corrosion thinning & [70] & 6202 \\
\hline & & & Defect of pipe & {$[70]$} & 6203 \\
\hline & & & Interference from the third party & {$[70]$} & 6204 \\
\hline & & & Incorrect operation & {$[70]$} & 6205 \\
\hline & & & Corrosion fatigue & [70] & 6206 \\
\hline & & & Unsuitable material & {$[70]$} & 6207 \\
\hline & & & $\begin{array}{l}\text { Blocking of the drilling pipe or product } \\
\text { pipe installation due to the swelling of } \\
\text { clay and silt }\end{array}$ & {$[66]$} & 6208 \\
\hline & & & $\begin{array}{l}\text { Sudden shock to the lines and the } \\
\text { possibility of bursting pipes and fittings }\end{array}$ & Survey & 6209 \\
\hline & & & $\begin{array}{l}\text { Lack of a needle valve to } \\
\text { relieve pressure }\end{array}$ & Survey & 6210 \\
\hline & & & $\begin{array}{l}\text { Faulty pipe connections: the improper } \\
\text { fusion/welding of pipes }\end{array}$ & {$[62]$} & 6211 \\
\hline & & & $\begin{array}{l}\text { Inappropriate selection of external } \\
\text { tube coating }\end{array}$ & {$[62]$} & 6212 \\
\hline & & & Tight hole stuck pipe & [69] & 6213 \\
\hline
\end{tabular}


Table A1. Cont.

\begin{tabular}{|c|c|c|c|c|c|}
\hline RBS Level 0 & RBS Level 1 & RBS Level 2 & RBS Level 3 & References & RBS Code \\
\hline & & \multirow{14}{*}{ Cementing } & Cementing of long casing strings & [35] & 6301 \\
\hline & & & $\begin{array}{l}\text { Increase the well cavity and } \\
\text { cementing problems }\end{array}$ & {$[62]$} & 6302 \\
\hline & & & $\begin{array}{l}\text { Problems in casing cementing and } \\
\text { Staying cement in casing }\end{array}$ & Survey & 6303 \\
\hline & & & Improper quality of cement slurry & Survey & 6304 \\
\hline & & & $\begin{array}{l}\text { Error in the amount of material added to } \\
\text { the cement }\end{array}$ & {$[71]$} & 6305 \\
\hline & & & $\begin{array}{l}\text { Contamination of cement liquid with } \\
\text { drilling mud or other caustic fluids }\end{array}$ & {$[71]$} & 6306 \\
\hline & & & $\begin{array}{l}\text { Error in choosing the type of } \\
\text { cement class }\end{array}$ & [71] & 6307 \\
\hline & & & $\begin{array}{l}\text { Error in measuring the correct weight } \\
\text { of cement }\end{array}$ & [71] & 6308 \\
\hline & & & Cement Shrinkage & [71] & 6309 \\
\hline & & & $\begin{array}{l}\text { Insufficient drilling mud to replace } \\
\text { cement inside the casing }\end{array}$ & {$[71]$} & 6310 \\
\hline & & & $\begin{array}{l}\text { Error in calculating the amount of } \\
\text { cement required for the pipe }\end{array}$ & {$[71]$} & 6311 \\
\hline & & & $\begin{array}{l}\text { Non-compliance of cement program } \\
\text { with operations and wells as a result of } \\
\text { not performing the required } \\
\text { tests correctly }\end{array}$ & Survey & 6312 \\
\hline & & & $\begin{array}{l}\text { Plugging the route of cementing } \\
\text { during operation }\end{array}$ & Survey & 6313 \\
\hline & & & $\begin{array}{l}\text { Leakage of the route of cementing } \\
\text { during operation }\end{array}$ & Survey & 6314 \\
\hline & & \multirow{2}{*}{$\begin{array}{l}\text { Loss of } \\
\text { circulation }\end{array}$} & $\begin{array}{l}\text { Formations that are inherently fractured, } \\
\text { cavernous, or have high permeability }\end{array}$ & [69] & 6401 \\
\hline & & & Highly fractured formations & {$[72]$} & 6402 \\
\hline & & \multirow{5}{*}{ Drilling Mud } & Infiltration of mud into wells & Survey & 6501 \\
\hline & & & Insufficient mud weight & [73] & 6502 \\
\hline & & & Not testing the mud properties & {$[62]$} & 6503 \\
\hline & & & $\begin{array}{l}\text { Not testing water for the drilling fluid } \\
\text { preparation }\end{array}$ & [62] & 6504 \\
\hline & & & Drilling fluid seepage & [66] & 6505 \\
\hline & & \multirow{7}{*}{$\begin{array}{l}\text { Blow out } \\
\text { contingency }\end{array}$} & $\begin{array}{l}\text { Facing the high pressure layer in the } \\
\text { drilling formation }\end{array}$ & [71] & 6601 \\
\hline & & & Plug annulus & [71] & 6602 \\
\hline & & & Annular Loss & [71] & 6603 \\
\hline & & & Temperature effects on drilling fluid & [71] & 6604 \\
\hline & & & Cut Mud & [71] & 6605 \\
\hline & & & Error in density measuring equipment & [71] & 6606 \\
\hline & & & $\begin{array}{l}\text { Operator error in mixing the correct } \\
\text { drilling fluid density }\end{array}$ & [71] & 6607 \\
\hline
\end{tabular}


Table A1. Cont.

\begin{tabular}{|c|c|c|c|c|c|}
\hline RBS Level 0 & RBS Level 1 & RBS Level 2 & RBS Level 3 & References & RBS Code \\
\hline & & & Improper casing running & {$[71]$} & 6608 \\
\hline & & & Error inspecting Casing & [71] & 6609 \\
\hline & & & Error inspecting Cementing & [71] & 6610 \\
\hline & & & Collapsing formation & [74] & 6701 \\
\hline & & & Mechanical failure by in-situ stresses & [69] & 6702 \\
\hline & & $\begin{array}{l}\text { Wellbore } \\
\text { instability }\end{array}$ & Erosion caused by fluid circulation & [69] & 6703 \\
\hline & & & $\begin{array}{l}\text { Chemical caused by interaction of } \\
\text { borehole fluid with the formation }\end{array}$ & [69] & 6704 \\
\hline & & & Wellbore shrinkage & [75] & 6705 \\
\hline & & & Corrosion or wear of mechanical parts & {$[60]$} & 6801 \\
\hline & & & $\begin{array}{l}\text { Effect of Ageing; wear and tear, worn or } \\
\text { fatigued part }\end{array}$ & [35] & 6802 \\
\hline & & & $\begin{array}{l}\text { Equipment quality (special equipment; } \\
\text { delay; damaged) }\end{array}$ & [35] & 6803 \\
\hline & & & $\begin{array}{l}\text { Inadequate equipment for more } \\
\text { high-tech production }\end{array}$ & {$[63]$} & 6804 \\
\hline & & Equipment & $\begin{array}{l}\text { Inadequate equipment with type } \\
\text { of operation }\end{array}$ & Survey & 6805 \\
\hline & & & Poor maintenance program & {$[60]$} & 6806 \\
\hline & & & Operational and resource limits & [35] & 6807 \\
\hline & & & $\begin{array}{l}\text { Material suitability and defects; } \\
\text { Fabrication defects }\end{array}$ & [35] & 6808 \\
\hline & & & Equipment Failure & [75] & 6809 \\
\hline & & & Equipment failure due to $\mathrm{H} 2 \mathrm{~S}$ gas & {$[62]$} & 6810 \\
\hline & & & $\begin{array}{l}\text { New technology (e.g., packers and } \\
\text { liner hangers) }\end{array}$ & [35] & 6901 \\
\hline & & & Immaturity of new technology & {$[61]$} & 6902 \\
\hline & & Technology & Complex technologies & Survey & 6903 \\
\hline & & & $\begin{array}{l}\text { Lack of access to new technologies in } \\
\text { geophysics and earth sciences }\end{array}$ & Survey & 6904 \\
\hline & & & Risk of changes in upstream technology & Survey & 6905 \\
\hline & \multirow{3}{*}{$\begin{array}{l}\text { HSE Risk-Health and } \\
\text { Safety }\end{array}$} & \multirow{3}{*}{$\begin{array}{l}\text { Drilling } \\
\text { operation }\end{array}$} & $\begin{array}{l}\text { Start of drilling, Increasing pressure and } \\
\text { cracking high-pressure lines of drilling } \\
\text { fluid, colliding lines with people }\end{array}$ & Survey & 7101 \\
\hline & & & $\begin{array}{l}\text { Casing running, Falling suspended } \\
\text { loads, work at heights, fatal falls, Stuck } \\
\text { organs, collisions of pipes with people, } \\
\text { collisions of elevators with the position } \\
\text { of casing derrick man }\end{array}$ & Survey & 7102 \\
\hline & & & $\begin{array}{l}\text { Perforation, Falling suspended load, } \\
\text { ergonomic damage, risk of employees } \\
\text { falling from a height, hitting hammers } \\
\text { on people, cracking of lines under } \\
\text { pressure, explosion due to impact and } \\
\text { electric current and lightning strike }\end{array}$ & Survey & 7103 \\
\hline
\end{tabular}


Table A1. Cont.

\begin{tabular}{|c|c|c|c|c|c|}
\hline RBS Level 0 & RBS Level 1 & RBS Level 2 & RBS Level 3 & References & RBS Code \\
\hline & & & $\begin{array}{l}\text { Acidizing, Cracking of lines and hitting } \\
\text { people, Acid spraying and severe acid } \\
\text { burns, skeletal injuries }\end{array}$ & Survey & 7104 \\
\hline & & & $\begin{array}{l}\text { Cementing, Equipment damage, } \\
\text { ergonomic discomfort, hearing } \\
\text { problems, engine heat, heat stress, } \\
\text { working with pressurized lines, tearing } \\
\text { or cracking of lines, dust, falling and } \\
\text { collision of equipment with people }\end{array}$ & Survey & 7105 \\
\hline & & & $\begin{array}{l}\text { Air drilling, Cracking of lines and } \\
\text { hitting people, Abnormal and } \\
\text { unusual noise }\end{array}$ & Survey & 7106 \\
\hline & & & $\begin{array}{l}\text { Underbalanced drilling, Hitting the } \\
\text { plexus, ergonomic injuries, working at } \\
\text { height and risk of falling from a height, } \\
\text { hitting joints, shifting load, risk of } \\
\text { falling load }\end{array}$ & Survey & 7107 \\
\hline & & & $\begin{array}{l}\text { Well Logging, Stuck of body parts, } \\
\text { skeletal and muscular injuries, } \\
\text { ergonomic injuries, noise, falling of } \\
\text { equipment, collision of a tube stand } \\
\text { with the position of the derrick man and } \\
\text { damage to the position of the } \\
\text { derrick man }\end{array}$ & Survey & 7108 \\
\hline & & \multirow{6}{*}{$\begin{array}{l}\text { Drilling } \\
\text { equipment }\end{array}$} & $\begin{array}{l}\text { Drilling rig installation, Stuck body } \\
\text { parts between equipment, risk of falling } \\
\text { load, falling from a height }\end{array}$ & Survey & 7201 \\
\hline & & & $\begin{array}{l}\text { Capsule storage, Sudden explosion of } \\
\text { cylinders during displacement of toxic } \\
\text { and combustible gas leaks, fire }\end{array}$ & Survey & 7202 \\
\hline & & & $\begin{array}{l}\text { Power supply device, Fire, stuck of } \\
\text { organs inside machines and amputation, } \\
\text { electrocution, burns caused by } \\
\text { electric shock }\end{array}$ & Survey & 7203 \\
\hline & & & $\begin{array}{l}\text { Raise BOP, Work at height and risk of } \\
\text { fatal fall, Risk of falling suspended loads }\end{array}$ & Survey & 7204 \\
\hline & & & $\begin{array}{l}\text { Coiled Tubing, Ergonomic injuries, } \\
\text { collisions and damage to equipment and } \\
\text { people, risk of falling, working with air } \\
\text { lifts, working with pressure lines, } \\
\text { cracking lines, spraying acid or diesel on } \\
\text { people, skeletal and muscular injuries }\end{array}$ & Survey & 7205 \\
\hline & & & $\begin{array}{l}\text { BOP Test, Slipping, Infiltration of mud } \\
\text { and fluids into people's eyes, falling into } \\
\text { mud pit, Work at height, Failure to } \\
\text { operate safety valves for drilling mud } \\
\text { pumps, cracking of pressure lines, } \\
\text { Elevators collide with people }\end{array}$ & Survey & 7206 \\
\hline
\end{tabular}


Table A1. Cont.

\begin{tabular}{|c|c|c|c|c|c|}
\hline RBS Level 0 & RBS Level 1 & RBS Level 2 & RBS Level 3 & References & RBS Code \\
\hline & \multirow{28}{*}{$\begin{array}{l}\text { HSE Risk- } \\
\text { Environment }\end{array}$} & \multirow{9}{*}{$\begin{array}{l}\text { Drilling } \\
\text { operation }\end{array}$} & Groundwater contamination & [76] & 8101 \\
\hline & & & Surface water contamination & [76] & 8102 \\
\hline & & & Releases to air (local air quality) & [77] & 8103 \\
\hline & & & $\begin{array}{l}\text { Releases to air (contribution to } \\
\text { global warming) }\end{array}$ & [77] & 8104 \\
\hline & & & Visual impact & [76] & 8105 \\
\hline & & & Biodiversity impacts & [76] & 8106 \\
\hline & & & Land take & [76] & 8107 \\
\hline & & & Noise & {$[76]$} & 8108 \\
\hline & & & Traffic & [76] & 8109 \\
\hline & & \multirow{3}{*}{$\begin{array}{l}\text { Drilling fluid } \\
\text { discharge }\end{array}$} & Soil pollution by drilling fluid & Survey & 8201 \\
\hline & & & Groundwater pollution by drilling fluid & Survey & 8202 \\
\hline & & & Adverse effects on wildlife & Survey & 8203 \\
\hline & & \multirow{4}{*}{$\begin{array}{l}\text { Disposal and } \\
\text { discharge of } \\
\text { wastewater }\end{array}$} & Soil pollution by wastewater & Survey & 8301 \\
\hline & & & $\begin{array}{l}\text { Visual impact in case of discharge to } \\
\text { water resources }\end{array}$ & Survey & 8302 \\
\hline & & & Water pollution by wastewater & Survey & 8303 \\
\hline & & & $\begin{array}{l}\text { Unpleasant odor emissions into the } \\
\text { environment }\end{array}$ & Survey & 8304 \\
\hline & & \multirow{4}{*}{$\begin{array}{c}\text { Acid } \\
\text { deposition }\end{array}$} & Soil pollution by acid & Survey & 8401 \\
\hline & & & Air pollution caused by acid vapors & Survey & 8402 \\
\hline & & & Unpleasant odor of acid & Survey & 8403 \\
\hline & & & Groundwater pollution by acid & Survey & 8404 \\
\hline & & \multirow{8}{*}{$\begin{array}{c}\text { Oil and gas } \\
\text { leaks, toxic gas } \\
\text { leaks, waste or } \\
\text { other } \\
\text { environmental } \\
\text { pollutants }\end{array}$} & $\begin{array}{l}\text { Reduction of biodiversity of organisms } \\
\text { due to biological accumulation of } \\
\text { hydrocarbons }\end{array}$ & Survey & 8501 \\
\hline & & & $\begin{array}{l}\text { Damage to birds due to ingestion of } \\
\text { petroleum products }\end{array}$ & Survey & 8502 \\
\hline & & & $\begin{array}{l}\text { Biological accumulation of petroleum } \\
\text { substances in the body of organisms }\end{array}$ & Survey & 8503 \\
\hline & & & Chronic effects for humans & Survey & 8504 \\
\hline & & & $\begin{array}{l}\text { Hypothermia and death of } \\
\text { mammals/birds }\end{array}$ & Survey & 8505 \\
\hline & & & Fire and damage to equipment & Survey & 8506 \\
\hline & & & Explosion & Survey & 8507 \\
\hline & & & Air pollution by gas & Survey & 8508 \\
\hline
\end{tabular}

\section{References}

1. Romagnoli, R.; Alkychyyev, D. Innovative Drilling and Completion Technologies. Ph.D. Thesis, Politecnico di Torino, Turin, Italy, 2020.

2. Marjoribanks, R. Drilling: A General Discussion the Importance of Drilling. In Geological Methods in Mineral Exploration and Mining; Springer: Berlin/Heidelberg, Germany, 2010; pp. 75-84.

3. Okwiri, L.A. Risk Assessment and Risk Modelling in Geothermal Drilling. Master's Thesis, Iceland School of Energy, Reykjavík, Iceland, 2017.

4. Jahn, F.; Cook, M.; Graham, M. Hydrocarbon Exploration and Production; Elsevier: Amsterdam, The Netherlands, 2008; ISBN 0080568831 
5. Devereux, S. Drilling Technology in Nontechnical Language; PennWell Books: Tulsa, OK, USA, 1999; ISBN 0878147624.

6. Schanche, L.E.; Steffensen, E.E. Valuation of Maersk Drilling. Master's Thesis, Copenhagen Business School, Frederiksberg, Denmark, 2020.

7. Stewart, A.M.Y.E. Indemnification and Insurance: Contractual Risk Transfer Provisions. Amystewartlaw 2020, 1, 5.

8. Faraji, A. Smart Contract Based Conceptual Model for Optimizing Risk Distribution in Construction Industry. In Proceedings of the 3rd International Conference on Applied Researches in Structual Engineering and Construction Management, Chicago, IL, USA, 20-25 May 2019.

9. Rahman, S.; Odeyinka, H.; Perera, S.; Bi, Y. Product-cost modelling approach for the development of a decision support system for optimal roofing material selection. Expert Syst. Appl. 2012, 39, 6857-6871. [CrossRef]

10. Mohammadi, M. Maria Rashidi, Maryam Ghodrat, Bijan Samali and. Manag. Inf. Syst. 2018, 19, 22.

11. Faraji, A.; Rashidi, M.; Sorooshnia, E. An Integrated Organizational System for Project Source Selection in the Major Iranian Construction Companies. Buildings 2020, 10, 251. [CrossRef]

12. Marietta, K.; White, M. Drilling Contracts: Avoiding Misunderstanding. Energy Newsl. 2015, 1, 7.

13. Anderson, O.L. The anatomy of an oil and gas drilling contract. Tulsa LJ 1989, 25, 359.

14. Brown, L.B.; Flanagan, H.J. Onshore Drilling Contracts: Avoiding the Pitfalls of Form Drilling Contracts; Rocky Mountain Mineral Law Foundation: Westminster, CO, USA, 2004.

15. Ottinger, P.S. Drilling Contracts. Ann. Inst. Min. L 1992, 38, 99.

16. Caraballo, C.H.; Bastidas, G.E.; Torres, A.J. Experiences On New Types Of Drilling Contracts. In Proceedings of the IADC/SPE Drilling Conference, Dallas, TX, USA, 3-6 March 1998; Society of Petroleum Engineers: Richardson, TX, USA, 1998.

17. De Wardt, J.D.P. Drilling in the Twilight Zone: Somewhere Between Dayrate and Turnkey. In Proceedings of the SPE/IADC Drilling Conference, Amsterdam, The Netherlands, 22-25 February 1993; Society of Petroleum Engineers: Richardson, TX, USA, 1993.

18. Kaiser, M.J.; Snyder, B. A Primer on the Offshore Contract Drilling Industry. Ocean Dev. Int. Law 2013, 44, 287-314. [CrossRef]

19. Miyora, T.O. Modelling and Optimization of Geothermal Drilling Parameters: A Case Study of Well MW-17 in Menengai, Kenya; United Nations University: Tokyo, Japan, 2014; ISBN 9979683449.

20. Bret-Rouzaut, N.; Favennec, J.-P. Oil and Gas Exploration and Production: Reserves, Costs, Contracts; Editions Technip: Paris, France, 2011; ISBN 2710809753.

21. Oeffner, J.A. New type of drilling contract minimizes well costs by guaranteeing performance. J. Pet. Technol. 1988, 40, 363-371.

22. Kaiser, M.J.; Snyder, B.; Pulsipher, A.G. Offshore Drilling Industry and Rig Construction Market in the Gulf of Mexico; UBureau of Ocean Energy Management, Gulf of Mexico OCS Region: Washington, DC, USA, 2013.

23. Moomjian, C.A., Jr. Incentive drilling contracts: A logical approach for enhancement of drilling efficiency. SPE Drill. Eng. 1992, 7, 9-14. [CrossRef]

24. Jennings, A. Oil and Gas Exploration Contracts; Sweet \& Maxwell: London, UK, 2002; ISBN 0421829206.

25. Aven, T. On how to define, understand and describe risk. Reliab. Eng. Syst. Saf. 2010, 95, 623-631. [CrossRef]

26. Wideman, R.M. Project and Program Risk Management: A Guide to Managing Project Risks and Opportunities. Ph.D. Thesis, Univerza v Ljubljani, Ljubljana, Slovenia, 1992.

27. Lowrance, W.W. Of Acceptable Risk: Science and the Determination of Safety; William Kaufmann, Inc.: Los Altos, CA, USA, 1976.

28. Guide 73: 2002: Risk Management Vocabulary Guidelines for use in standards. Int. Conf. Risk Assess. Manag. $2002,24,25$.

29. El-Sayegh, S.M. Risk assessment and allocation in the UAE construction industry. Int. J. Proj. Manag. 2008, 26, 431-438. [CrossRef]

30. Aven, T. An emerging new risk analysis science: Foundations and implications. Risk Anal. 2018, 38, 876-888. [CrossRef] [PubMed]

31. Nesticò, A.; He, S.; De Mare, G.; Benintendi, R.; Maselli, G. The ALARP principle in the Cost-Benefit analysis for the acceptability of investment risk. Sustainability 2018, 10, 4668. [CrossRef]

32. Amir-Heidari, P.; Farahani, H.; Ebrahemzadih, M. Risk assessment of oil and gas well drilling activities in Iran-a case study: Human factors. Int. J. Occup. Saf. Ergon. 2015, 21, 276-283. [CrossRef]

33. Pritchard, D.M. Drilling Hazards Management_Excellence in Drilling Performance Begins with Planning (Part 1 of DHM Series); Deepwater Horizon Study Group: Berkeley, CA, USA, 2010.

34. Gala, D.M.; York, P.; Pritchard, D.M.; Rosenberg, S.M.; Dodson, J.K.; Utama, B. Drilling Hazard Mitigation Technologies Key in Eliminating Non-Productive Time in Challenging Wells. In Proceedings of the SPE Oil and Gas India Conference and Exhibition; Society of Petroleum Engineers, Mumbai, India, 9-11 January 2010.

35. Yasseri, S. Drilling Risk Identification, Filtering, Ranking and Management. Int. J. Coast. Offshore Eng. 2017, 1, 17-26. [CrossRef]

36. Saha, L.; Bauddh, K. Characteristics of mining spoiled and oil drilling sites and adverse impacts of these activities on the environment and human health. In Phytorestoration of Abandoned Mining and Oil Drilling Sites; Elsevier: Amsterdam, The Netherlands, 2021; pp. 87-101.

37. Tewari, S.; Dwivedi, U.D.; Biswas, S. Intelligent Drilling of Oil and Gas Wells Using Response Surface Methodology and Artificial Bee Colony. Sustainability 2021, 13, 1664. [CrossRef]

38. Edition, P.G. A Guide to the Project Management Body of Konwledge; Project Management Institute: Newtown Square, PA, USA, 2018.

39. Barkley, B. Project Risk Management; McGraw Hill: New York, NY, USA, 2004; ISBN 007143691X.

40. Van Thuyet, N.; Ogunlana, S.O.; Dey, P.K. Risk management in oil and gas construction projects in Vietnam. Int. J. Energy Sect. Manag. 2007, 1, 175-194. [CrossRef] 
41. Rezaei, J. Best-worst multi-criteria decision-making method: Some properties and a linear model. Omega 2016, 64, 126-130. [CrossRef]

42. Rezaei, J.; Nispeling, T.; Sarkis, J.; Tavasszy, L. A supplier selection life cycle approach integrating traditional and environmental criteria using the best worst method. J. Clean. Prod. 2016, 135, 577-588. [CrossRef]

43. Rezaei, J.; Wang, J.; Tavasszy, L. Linking supplier development to supplier segmentation using Best Worst Method. Expert Syst. Appl. 2015, 42, 9152-9164. [CrossRef]

44. Javad, M.O.M.; Darvishi, M.; Javad, A.O.M. Green supplier selection for the steel industry using BWM and fuzzy TOPSIS: A case study of Khouzestan steel company. Sustain. Futur. 2020, 2, 100012. [CrossRef]

45. Youssef, A.E. An Integrated MCDM Approach for Cloud Service Selection Based on TOPSIS and BWM. IEEE Access 2020, 8 , 71851-71865. [CrossRef]

46. Bonyani, A.; Alimohammadlou, M. A new approach for evaluating international EPC contractors in Iran's energy sector. Int. J. Constr. Manag. 2020, 20, 775-782. [CrossRef]

47. Hashemi, H.; Mousavi, S.M.; Zavadskas, E.K.; Chalekaee, A.; Turskis, Z. A new group decision model based on grey-intuitionistic fuzzy-ELECTRE and VIKOR for contractor assessment problem. Sustainability 2018, 10, 1635. [CrossRef]

48. Maghsoodi, A.I.; Rasoulipanah, H.; López, L.M.; Liao, H.; Zavadskas, E.K. Integrating interval-valued multi-granular 2-tuple linguistic BWM-CODAS approach with target-based attributes: Site selection for a construction project. Comput. Ind. Eng. 2020, 139, 106147. [CrossRef]

49. Stević, Ž.; Pamučar, D.; Subotić, M.; Antuchevičiene, J.; Zavadskas, E.K. The location selection for roundabout construction using Rough BWM-Rough WASPAS approach based on a new Rough Hamy aggregator. Sustainability 2018, 10, 2817. [CrossRef]

50. Torabi, S.A.; Giahi, R.; Sahebjamnia, N. An enhanced risk assessment framework for business continuity management systems. Saf. Sci. 2016, 89, 201-218. [CrossRef]

51. Chang, T.-W.; Lo, H.-W.; Chen, K.-Y.; Liou, J.J.H. A novel FMEA model based on rough BWM and rough TOPSIS-AL for risk assessment. Mathematics 2019, 7, 874. [CrossRef]

52. Saaty, T.L. A scaling method for priorities in hierarchical structures. J. Math. Psychol. 1977, 15, 234-281. [CrossRef]

53. Saaty, T.L. Decision Making for Leaders: The Analytic Hierarchy Process for Decisions in a Complex World; RWS Publications: Pittsburgh, PA, USA, 1990; ISBN 1888603135.

54. Vargas, L.G. An overview of the analytic hierarchy process and its applications. Eur. J. Oper. Res. 1990, 48, 2-8. [CrossRef]

55. Rezaei, J. Best-worst multi-criteria decision-making method. Omega 2015, 53, 49-57. [CrossRef]

56. Rezaei, J.; Hemmes, A.; Tavasszy, L. Multi-criteria decision-making for complex bundling configurations in surface transportation of air freight. J. Air Transp. Manag. 2017, 61, 95-105. [CrossRef]

57. PMBOK. A Guide to the Project Management Body of Knowledge (PMBOK@Guide), 6th ed.; Project Management Institute: Newtown Square, PA, USA, 2017; ISBN 9781628253900.

58. Xiang, P.; Zhou, J.; Zhou, X.; Ye, K. Construction project risk management based on the view of asymmetric information. J. Constr Eng. Manag. 2012, 138, 1303-1311. [CrossRef]

59. Jones, M.S. Offshore and Onshore Drilling Contracts. Energy Symp. 2011, 1, 1-18.

60. Amir-Heidari, P.; Maknoon, R.; Taheri, B.; Bazyari, M. Identification of strategies to reduce accidents and losses in drilling industry by comprehensive HSE risk assessment-A case study in Iranian drilling industry. J. Loss Prev. Process Ind. 2016, 44, 405-413. [CrossRef]

61. Skogdalen, J.E.; Vinnem, J.E. Quantitative risk analysis of oil and gas drilling, using Deepwater Horizon as case study. Reliab. Eng. Syst. Saf. 2012, 100, 58-66. [CrossRef]

62. Aboumasoudi, A.S.; Behvandi, O. Identification and ranking risks of horizontal directional drilling for oil \& gas wells by using fuzzy analytic network process: A case study for Gachsaran oil field wells. J. Ind. Syst. Eng. 2019, 12, 46-60.

63. Lenkova, O.V. Risk management of oil and gas company in terms of strategic transformations. Risk Manag. 2018, 39, 30.

64. Abimbola, M.; Khan, F.; Khakzad, N. Dynamic safety risk analysis of offshore drilling. J. Loss Prev. Process Ind. $2014,30,74-85$. [CrossRef]

65. Yanting, Z.; Liyun, X. Research on Risk Management of Petroleum Operations. Energy Procedia 2011, 5, 2330-2334. [CrossRef]

66. Gierczak, M. The quantitative risk assessment of MINI, MIDI and MAXI horizontal directional drilling projects applying fuzzy fault tree analysis. Tunn. Undergr. Sp. Technol. 2014, 43, 67-77. [CrossRef]

67. Ketabchi, R.; Ghaeli, M. An application of fuzzy BWM for risk assessment in offshore oil projects. J. Proj. Manag. 2019, 4, 233-240. [CrossRef]

68. Chan, M. Fatigue: The most critical accident risk in oil and gas construction. Constr. Manag. Econ. 2011, 29, 341-353. [CrossRef]

69. Stumpf, A.J. Drilling Hazards. In Encyclopedia of Engineering Geology; Bobrowsky, P.T., Marker, B., Eds.; Springer International Publishing: Cham, Switzerland, 2018; pp. 244-248. ISBN 978-3-319-73568-9.

70. Shahriar, A.; Sadiq, R.; Tesfamariam, S. Risk analysis for oil \& gas pipelines: A sustainability assessment approach using fuzzy based bow-tie analysis. J. Loss Prev. Process Ind. 2012, 25, 505-523.

71. Mirzaie Aliabadi, M.; Mohammadfam, I. Risk Assessment of Oil and Gas Exploration Well Blowout in Drilling Operations Using Bow Tie Analysis and Bayesian Network. J. Occup. Hyg. Eng. 2018, 4, 59-69.

72. Lavrov, A. Lost Circulation: Mechanisms and Solutions; Gulf Professional Publishing: Houston, TX, USA, 2016 ; ISBN 0128039418. 
73. Abimbola, M.; Khan, F.; Khakzad, N.; Butt, S. Safety and risk analysis of managed pressure drilling operation using Bayesian network. Saf. Sci. 2015, 76, 133-144. [CrossRef]

74. Saleem Qadir Tunio, S.; Abdul Haque Tunio, A.H.; Naveed Ahmed Ghirano, N. Is It Possible to Ignore Problems Rising During Vertical Drilling? A Review. Res. J. Appl. Sci. Eng. Technol. 2011, 3, 1331-1336.

75. Zhang, L.; Wu, S.; Zheng, W.; Fan, J. A dynamic and quantitative risk assessment method with uncertainties for offshore managed pressure drilling phases. Saf. Sci. 2018, 104, 39-54. [CrossRef]

76. Corden, C.; Whiting, R.; Luscombe, D.; Power, O.; Ma, A.; Price, J.; Sharman, M.; Shorthose, J. Study on the Assessment and Management of Environmental Impacts and Risks Resulting from the Exploration and Production of Hydrocarbons; Final Report; Publications Office of the European Union: Luxembourg, 2016.

77. International Finance Corporation. Environmental, Health, and Safety Guidelines for Onshore Oil and Gas Development; International Finance Corporation: Washington, DC, USA, 2017; p. 47. 